$$
\begin{aligned}
& \text { ISUOY } \\
& \text { 1.2-3 ENZWARHASOEN }
\end{aligned}
$$

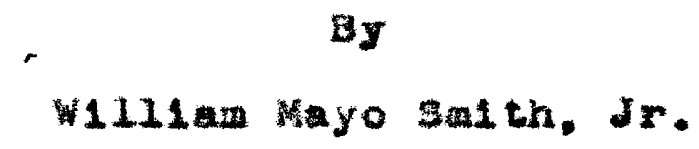

Thesla submitted to the Batity of the Gracuate school of the Univeralty of Maryland in partial fulfiliant of the requirementa for the atgree of Dootor of Ihilosophy

1947 
UMI Number: DP71117

All rights reserved

INFORMATION TO ALL USERS

The quality of this reproduction is dependent upon the quality of the copy submitted.

In the unlikely event that the author did not send a complete manuscript and there are missing pages, these will be noted. Also, if material had to be removed, a note will indicate the deletion.

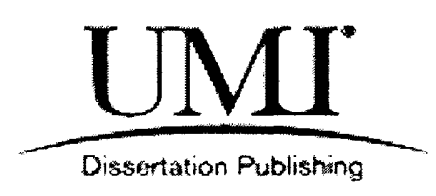

UMI DP71117

Published by ProQuest LLC (2015). Copyright in the Dissertation held by the Author.

Microform Edition (C) ProQuest LLC.

All rights reserved. This work is protected against

unauthorized copying under Title 17, United States Code

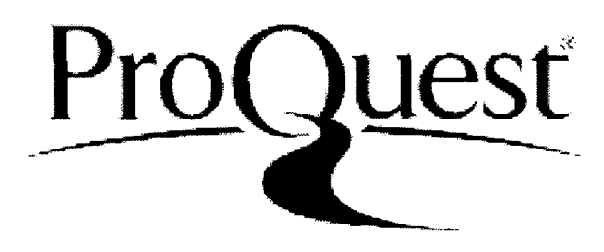

ProQuest LLC.

789 East Eisenhower Parkway

P.O. Box 1346

Ann Arbor, MI 48106 - 1346 


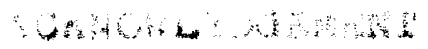

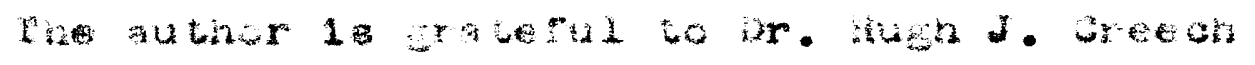

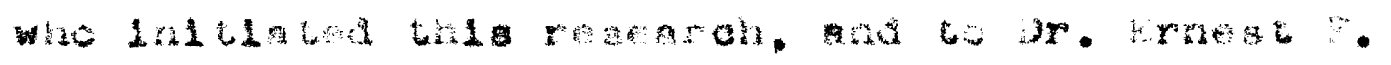

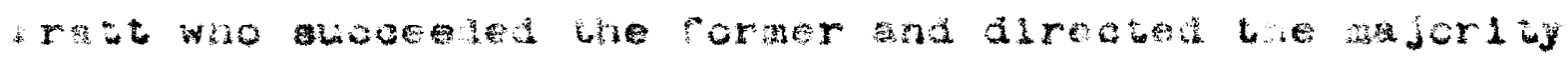

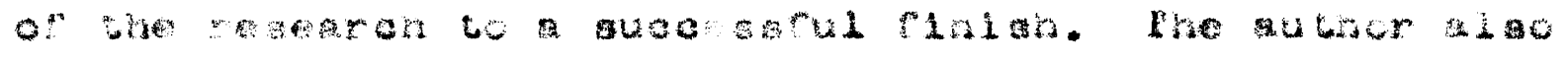

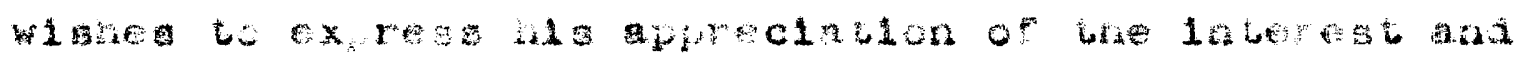

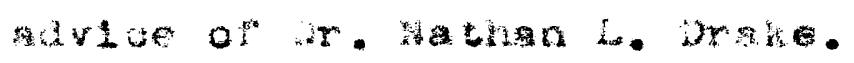




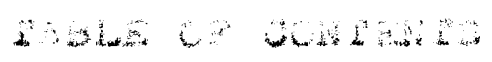

$-\mathrm{sig}^{0}$

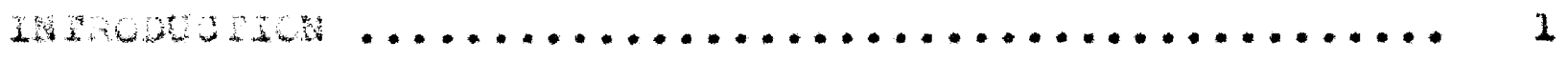

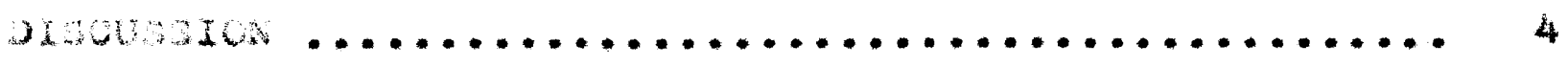

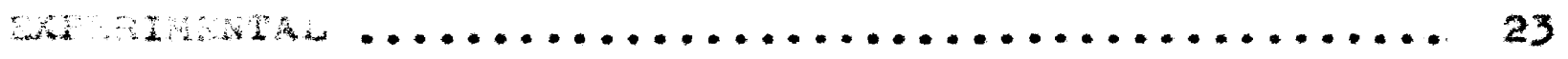

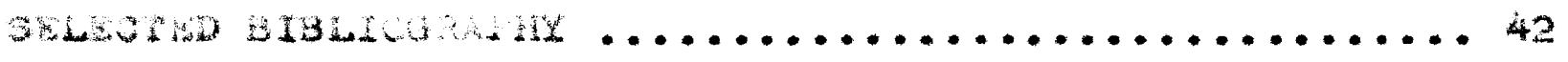




\section{IN THODORION}

In the early part of this century 1 was noted that persona dolre work whin regulrect lorg exposure to oon

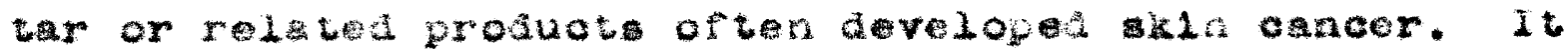

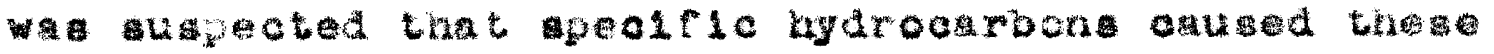
canow and in 1930 henaway and Heterer found that

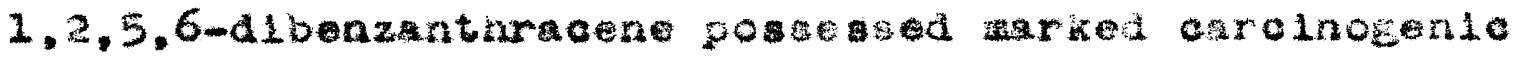
activ1ty.

S1noe that tiate laree number of hydrocarbons have

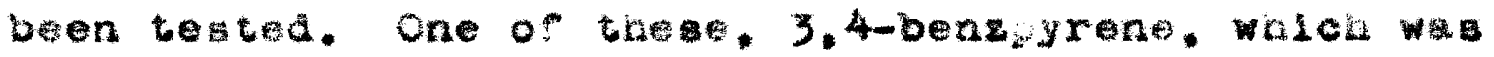

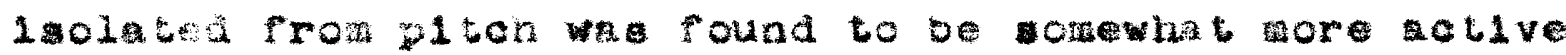
twa $1.2,5.6-d 1$ benzantiracate.

Cne of the nost powertul arelisedelo hydrocarbons 1. thyl cholanthren. Ihla can bo prepara troa dosoxyoholio acid and from cholsuterol, boto of whoh are normal conatituent of haman bile. The hypothesis has been

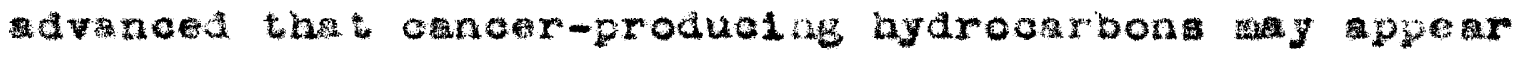

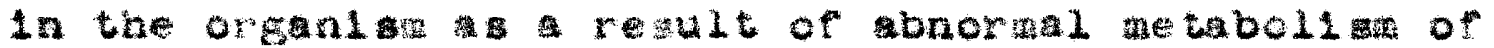
blle soids or other noral conatituenta of the body. 17 An laportant Beture comon to all of the co compound 1 tre provenoe of the aucleus of 1,2 -benzenthradene

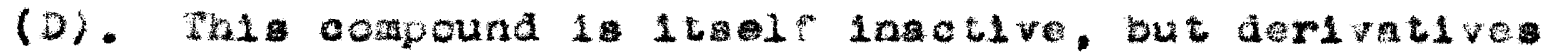

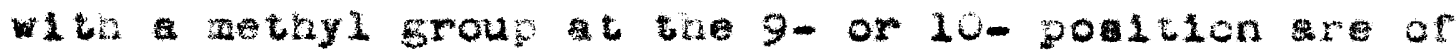
particular intorest. 10-Methyl-1,2-benzantaracene (E).

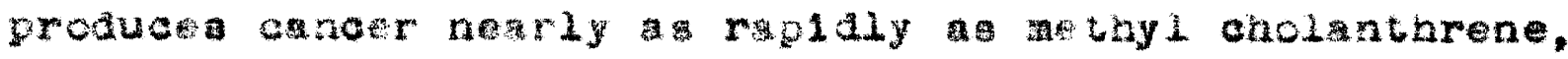

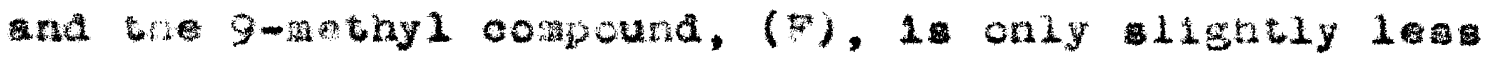
active. no 9,10-d1 thy 1-1,2-benzanthracne, (a), 1: 


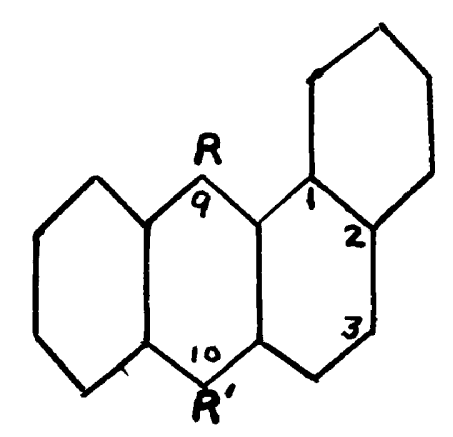

$$
\begin{aligned}
& \text { (D) } R=H ; \quad R^{\prime}=H
\end{aligned}
$$

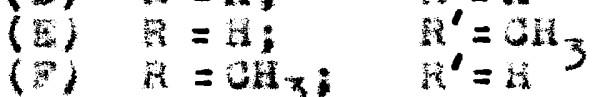

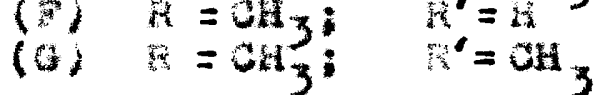

more potent than elther of the mononetayl compouna and

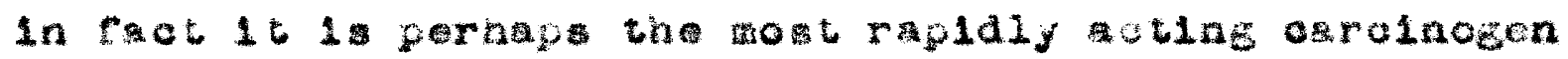
ixnown. 17

In the pat overal years a tudy nas been wade of certaln laoyanate acrivative of these actire byarocarbon 15 Among the mogt lmportant of the lsooganate

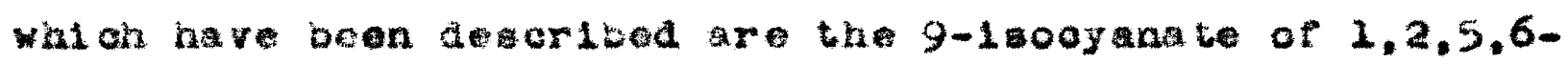

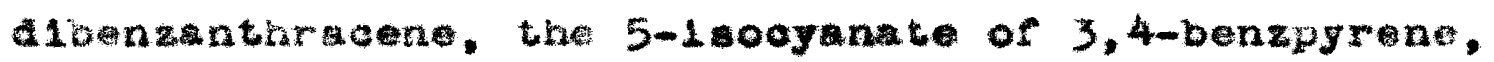
and the 3-10ocyanate of 10-methy 1-1,2-benzanthracene (E).

It ha been bhown that these laocyancte way be

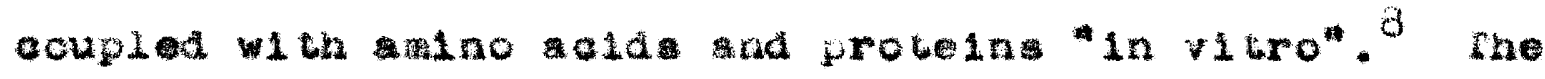

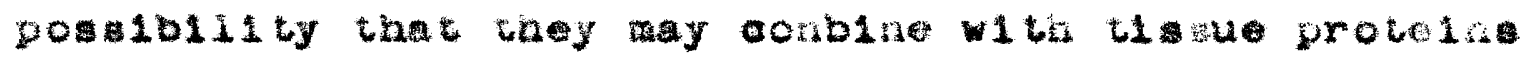
In vivo la wortay of conalderation. 7 It ayy bo pousble to produo ant1 sera from the aydrodamon-protoin conJughes which re capabie of preventing aydrocarbon oar- 


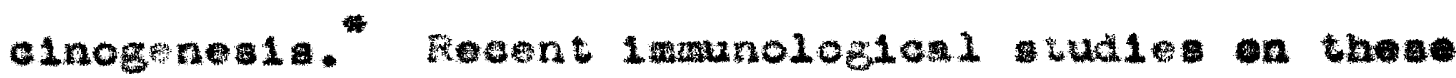
conjugates have prouroed reault or conelderable interest.

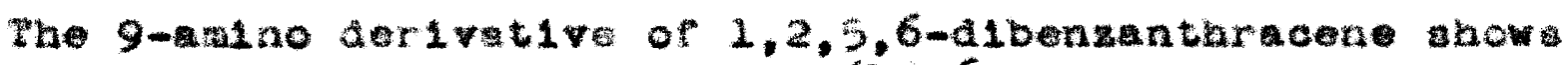

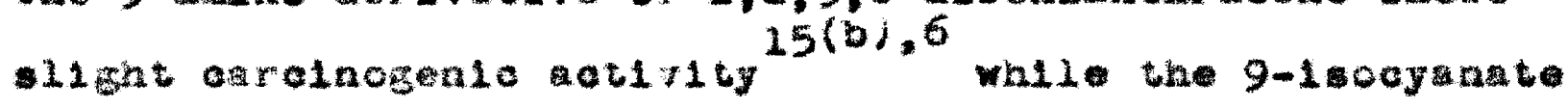

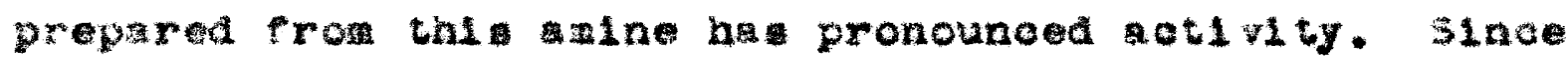
It cemed vry desrable that these atuale be extended. the ynthes of $9.10-$ almethyl-1,2-benzanthryl-3-1e0eyanate [(IX), F1gure I] and 9-methy1-1,2-benzantary 1-

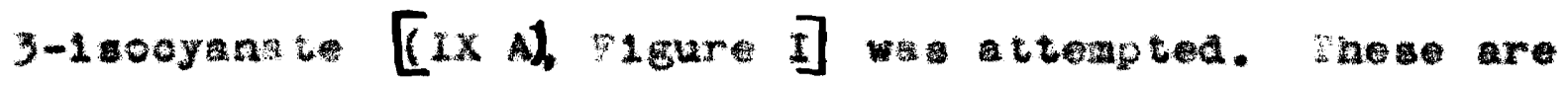

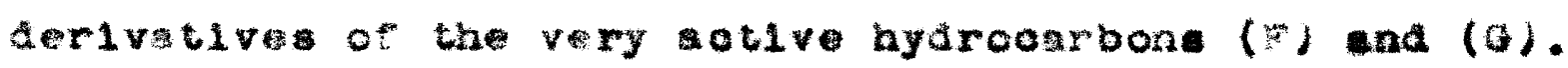

Dr.W. J. Orecth WII conduct thi work at the Lankenau

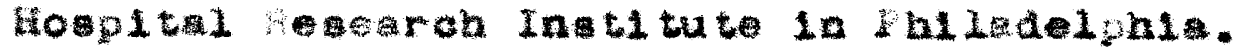




\section{SCUS3 IOH}

The thoda of aynthe 1e of 9.10-d1 the thy-1.2-benzanthry 2-3-1eoganate and of 9-mothy 1-1, 2-benzanthry 1-3leooyanate are outilned in the rollowlng chart (Plgure 1 ).

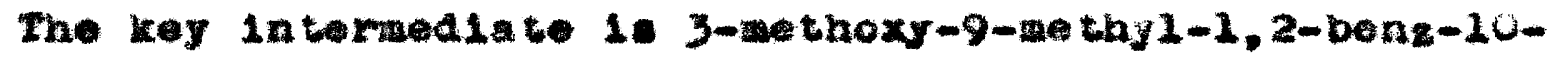
anthrone. It wa preparod from phthal1e anhyar1de and $\propto-$ methoxymaphthalene oy the four step eynthesic outlined. The anthrone is armatile intermal to. Not only were the two lacogana to (IX) and (IX A) ande from 1 t but two we thoxbenzanthracenes (XI) and (XII) whioh are unsymet-

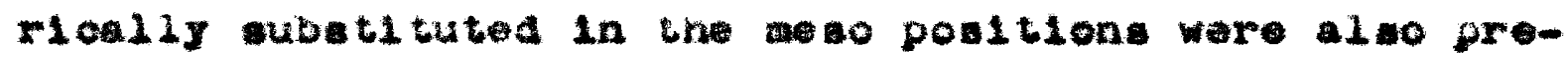
pared from tin 1mportant compound. An attompto oonvert the anthrone to 3.10-41we thoxy-9-wotny 1-1,2-benmanthreone *a unatroceasul.

Oreat diefloulty wa anoountered win two roactond of the synthesia but conditione wer rinally found under

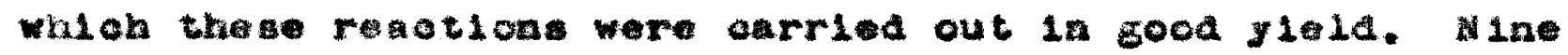
aucedsive reactons are required to convart $\alpha$-methoxynaphthelene to 1 ther the wono- or the almethy 1 benaanthryl 1eodranate (IX) and (IX A). The y lelda were good ror

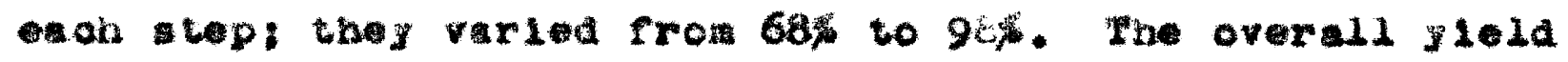
for the nine reactions va about $23 \%$ in ehoh oase. Stated In nother way. rifty-one grane of the alvethylbenzanthry 1.ooyanate (LX) coula be colalned from one muadred grame of $\alpha$ - the thoxy naphthalene.

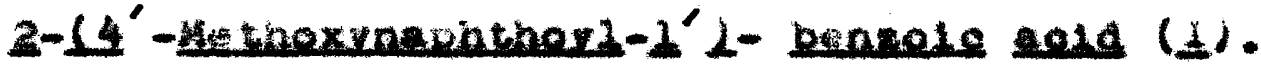

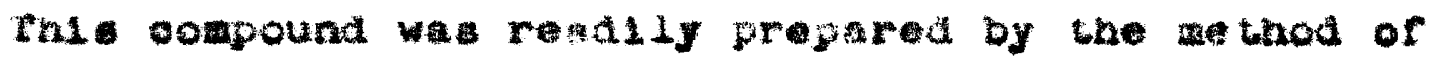




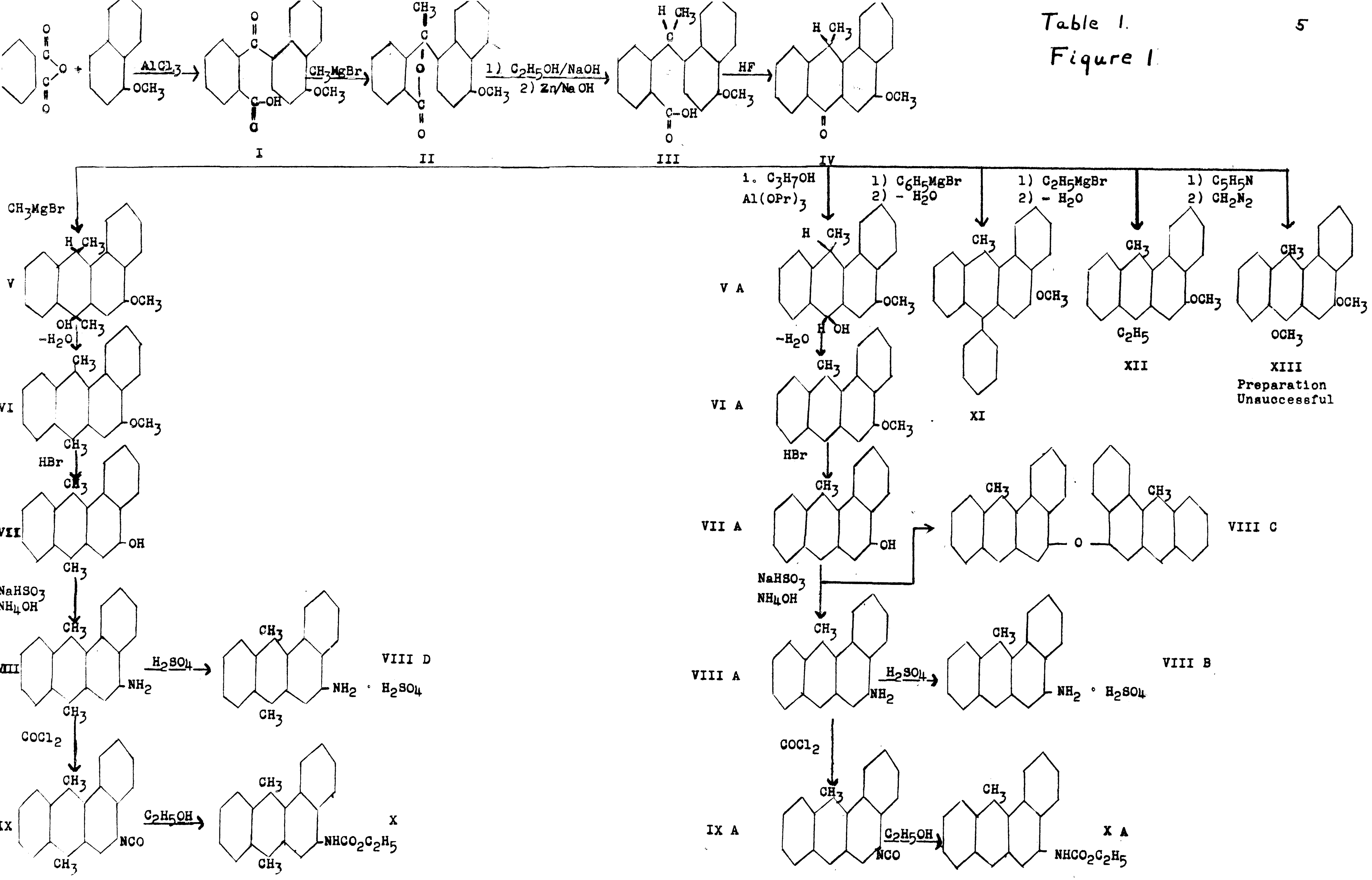


Pleser and Dietz. 16 ay atrioty controlling the reaction tempareture and ellminating the extremely wasterul decolorization wita oarbon. It wa posalble to laprove the purlty of the produd a great deal and at the asate time to ralde the gleld to $95 \%$ rroa $91 \%$.

This reation wa conveniently hendled in the laborntory using twloe the quantitle reportud in the experlatental part.

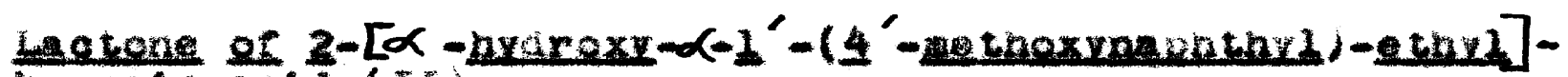
peareie natd (II).

The preparation of tha comound, Unine Hewan' method for synthesil of anothor laotone, 26 wa atengted by E. Wation or this Univeral by in Ootober. 1942. Repusted attenpte to ory talilze the rwation product were not sucesstul.

The author lio encountered affioulty in this oryalal1zetion unt1l the proper toonnlque nd solvents were round. Many golvento and solvent wixture were tried, but only the ones deacrlbed were round to be satisfatory. A toluen solution of the lactone wa conoentrated to - mall volume by ovajoracloa under reduced preseure. About one-third volume of aldoch wa aded and then petroletis other $\left(30-60^{\circ}\right)$ was very carerully added wita alase continuou owlrling until jut trace of turbldity appared. The mount of. petroluum ther was found to be orltion for the lishtost exces asused an oll to geparate. Upon cooling la a rerrigorator, the produet oryatallizad raplaly once seed orystat had forwed. In subsequent runs 


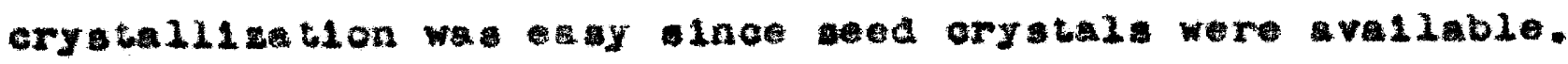

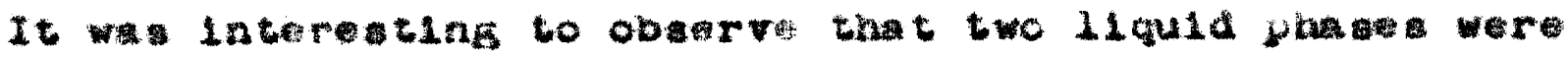

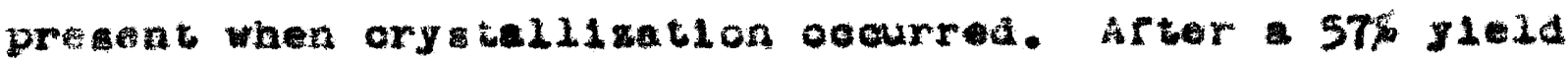
wa obtalned. no rurther lnotone would orystallize froa the now hoxogeneous solution. Further anlphiaton with

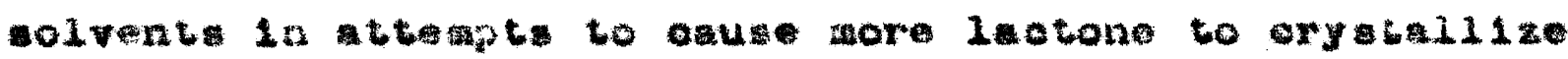
wa frulthess. It wa found, however. thet the orude Latone 1n the ather liquore could be realily purified by

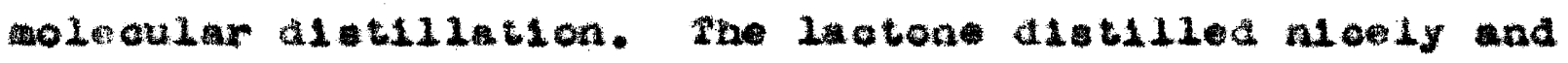

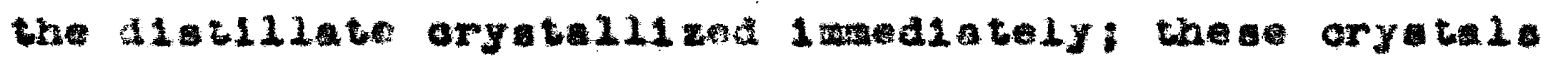
noltes th the me tomporature as tho ob obalnod rrow the bolvat and when alxturo of the oryetale from the two

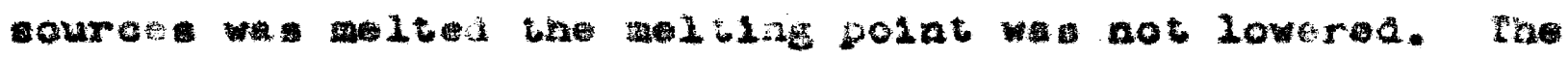
total yleld of oryatel. from botb cource was $70 \%$

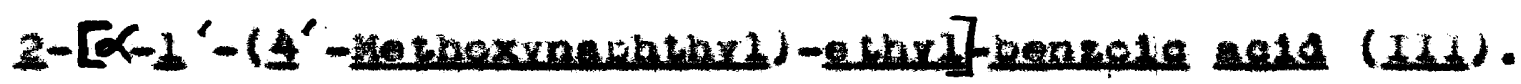
An thept wa made to clesto the lagtone to the aubet tutad benzolo sold by the olemenaen wethod of re-

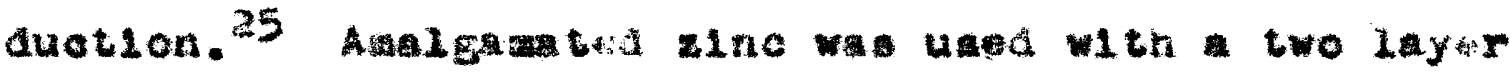
aolvent ayster ot hyaroahlorio nol. watr. and toluene.

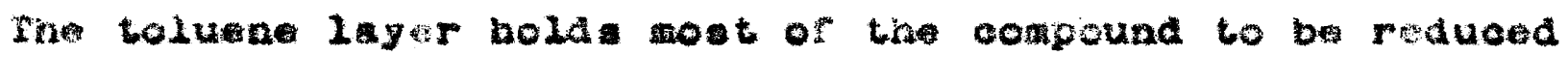

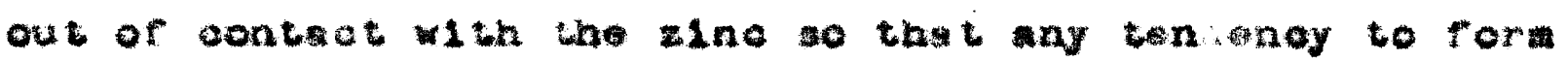
poigmolmcular oompound mics coat and thereby inactivio

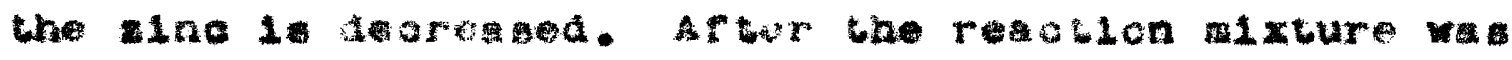

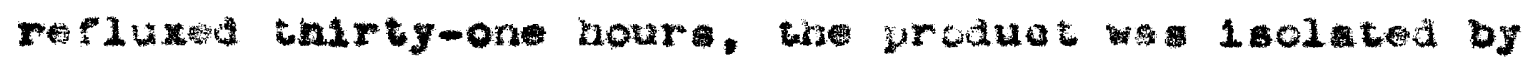
erysta112zation. It woltad at 143.1-145.9 and when it wa axed w1th tarting trat the 


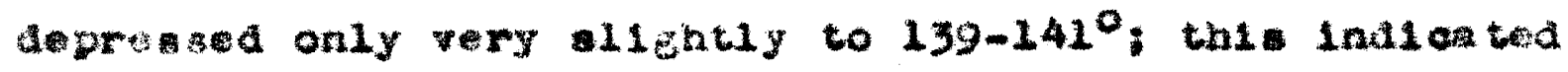
11tide reation had occurred.

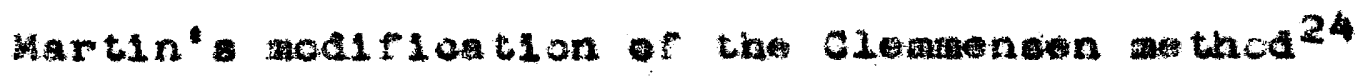

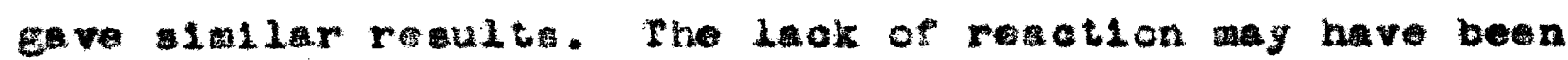
wue wo tarto hindrano for hartin was ble to roduce $\gamma$ -

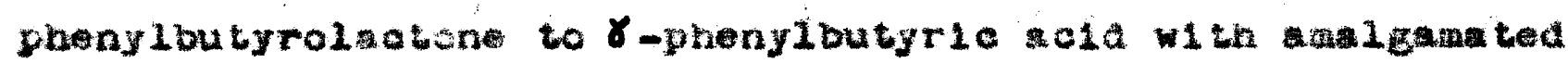
zise and hydroohiorie mold.

1. wa found that the aelrod acld could be obtalned

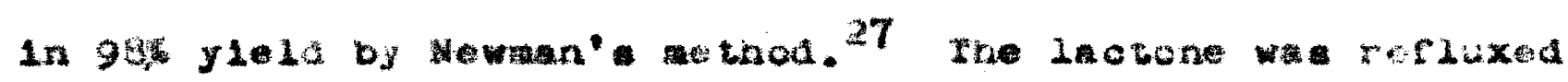

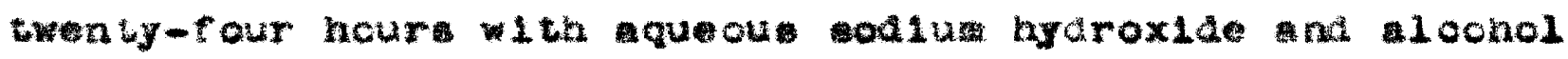

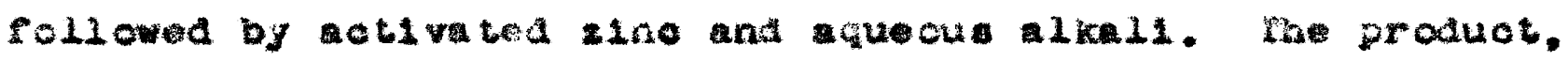

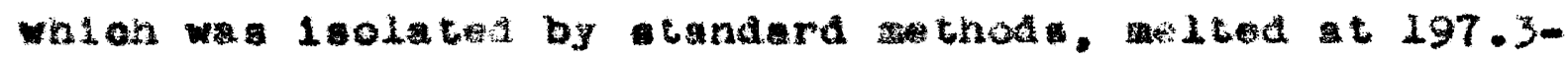
$19.1^{\circ}$

\section{3-1etinox $-9-12 \tan 1-1.2-$ benz-10-antarone (1V).}

Anhyaroue nyarofluorlo ald wa ued to oyclize the aubaticuted benzolo ela to the anthrone. 18 It wa round the by uslag an mount of nyarorluorle aela equivalent to

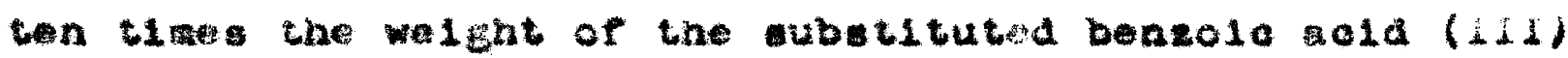
the acelred produat wa obtalned in zood yleld; the lare

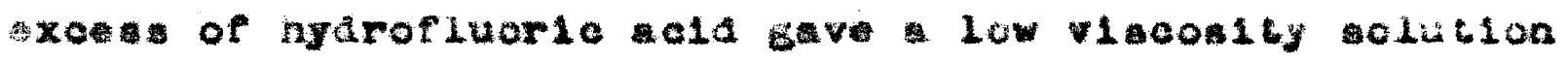
whio we convenignt to handie. Vigorous atirrine 1 a osentil aurine the adition of the renction alxture to pulvarizat loe if the foration of iuge waion interfere wth epleient waning 1 to bo volded. All tow to to

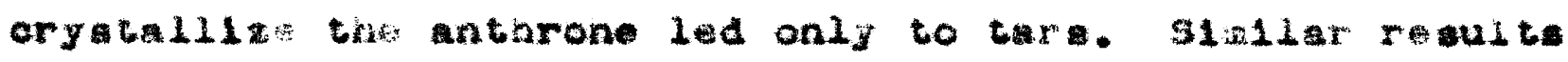

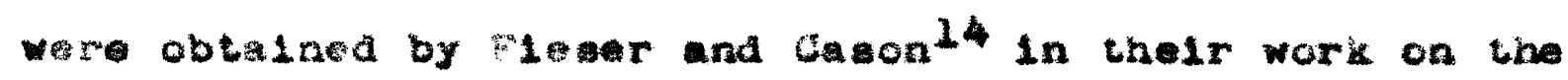
aycilzation of o-(7-acenaphuhyl)-benzolo acia with hydro-

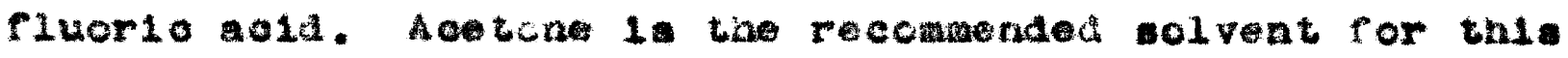


type of dompound for $1 \mathrm{t}$ fevor the butomerlation of the enol to the reto fort.

When the satiron wa prepart a deserlbed here. It wa round to be stable arter all oolvent and any other volatile waterial wa removed by alstildstion. This is in contrat to prevlou ravorts ${ }^{16}$ in whioh it is atated that olallar anthrone are very senaltive to heat and oxygen and therafore they wut be used lamediately fiter prepsation. In tal lavectighton anthrone which wa

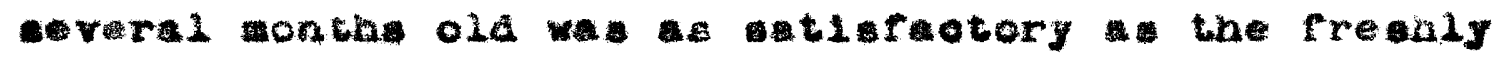
preparea aterlal. Consequently it wa posible to prepare

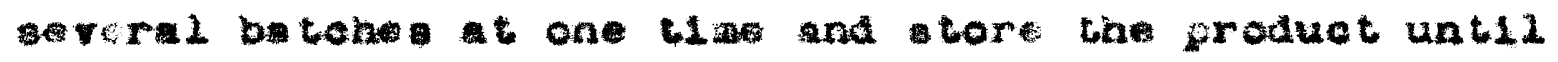

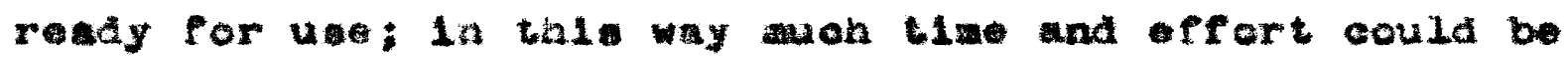
arad.

Thls anthrone 1. the langortant intermedate frow which the monomothyl wh Almethy 1 benzanthry 1 socyancte (IX) and (IX A) ware prepared.

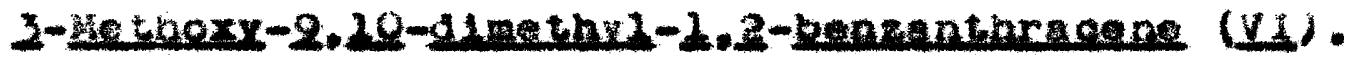

The intermediste tertiary alcohol (V) wa presared by tretsing the anthrone (IV) with mothylmagnesum bromide. The protuct coula not be obtained in pure, oryatal1ine

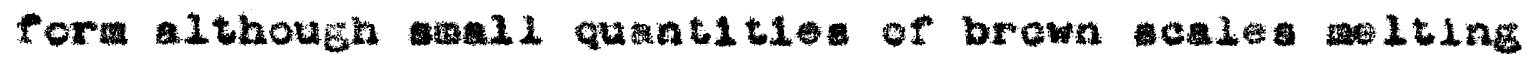
over a wide range in the vlolat ty of $200^{\circ}$ were orten

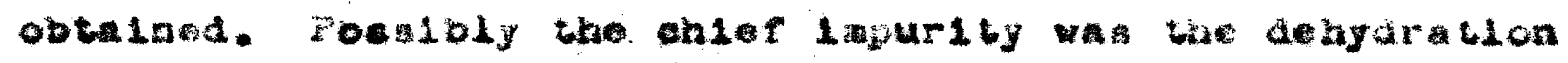
product $(V I)$, for upon heatine the orude tertiary aloohol on a hot plate $200^{\circ}$ the thexydlmethyl-benanchracene (VI) wh readily obtalned. Exoedive hethe lncreased 
the amount of ark, tarry material producod. rol orude debucrated product wa very ofrotively purlfied by con-

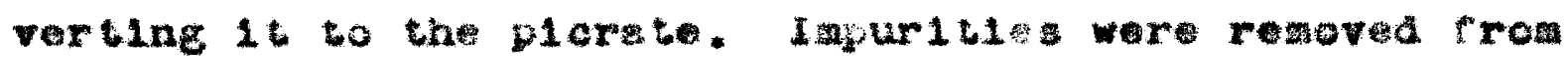
the plorate by adeorblat the from benzene colution on a

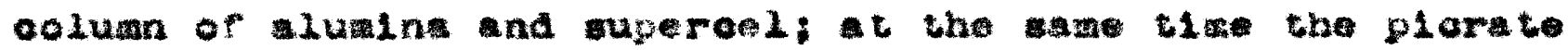
was dissoolated and a solution oontalning onty the desired produot pated though the coluan. Thi elution showed bright blus pluorescenoe and it wa cound that the lntenelty of the luoreachoe decreased the conoentrition of the colution Increasd. The extatuof of an o, tam conoen-

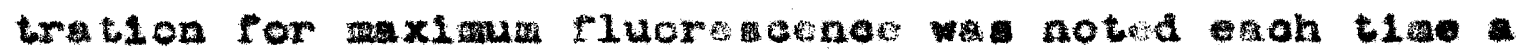
Pluoregont solution wh encountared in thla investigation. It wa round that two aderbtion columa elghtoen lnoho lonf and one and ont-hat Inche in alagewer woro uaually auflatent for the puriflation of tho atcunt of plarato obtalnad from oycliztion of a tweaty-f2ve gram batoh of

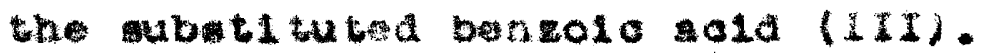

Jpon conesntration ant cooling of the purified benzene colution of the thoxy diothy-benantarecene (VI). Wellformed plats were obthinea in 62\% y1ela aloulated from

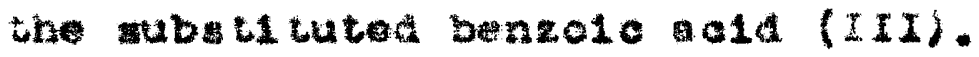

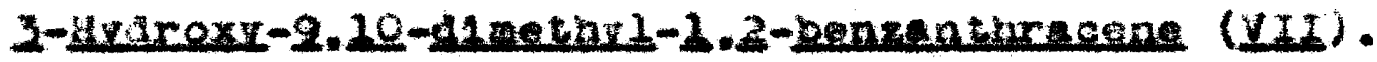

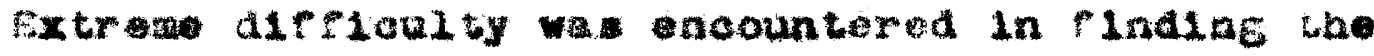
proper condltion for ourrylat out two or the reactione

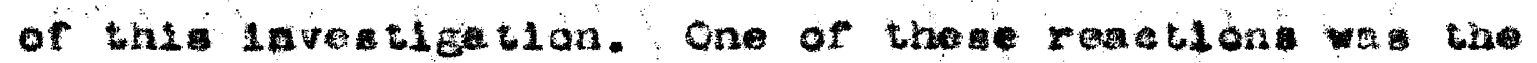
w1 ltine of the thoxy compound (VI) and (7I A) to tio oorrepond1ne hydroxg compounde. The other reaction wa 
the replsoenent of the aydroxy troup of (VII) and (VIIA) by andne group to give (VIII) and (VIIIA), respeotively.

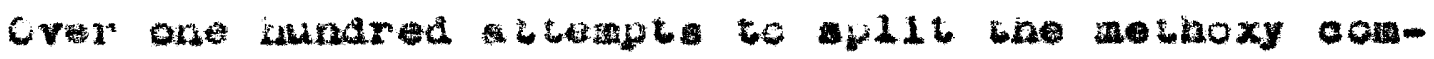
pouna under varlous condltiona were mate whbout suocea berore the proper condticna were roukd. Ind alfrieulty

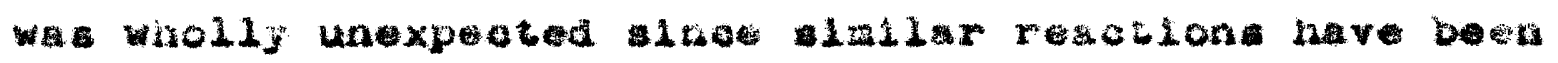
carried out tatactorily. 20 the uaul condilons ror oarryine out this raction and lare nuber of variation or the gave in evory ins cance products whon analyea Low la carbon and high in hydrogen.

3ose of the producta obtalned decomposed slowly when exposed to ir or vhen moletened with benzene while other turned fros yellow to ruby-rod almost instantiy. It is

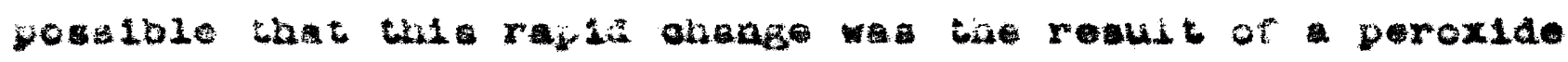
brldge porming aross the 9.10-posillon of the benzan-

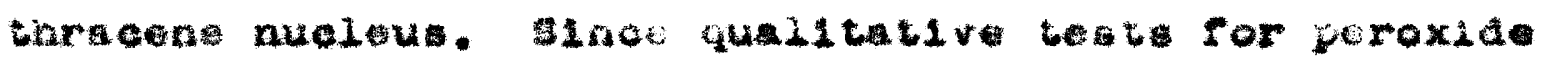
were negative. ay peroxides of this typ whlon cormed wat have ohnged raplaly into other deompoltion producto. Thoto-oxitintion of compcuncs of this tyjo ocour

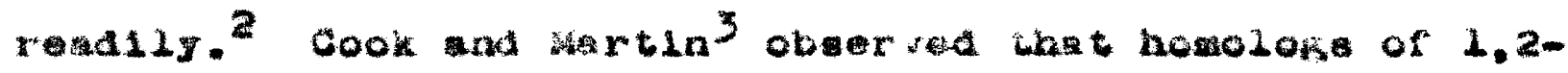
benzanthrocke w th substithent at one or both of the

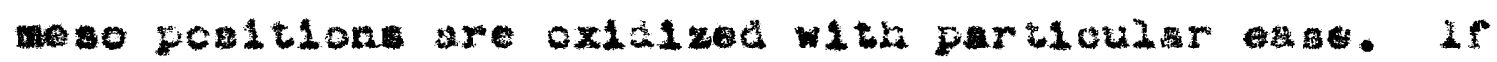
oxygen 10 gas throligh difute solubion of one of the

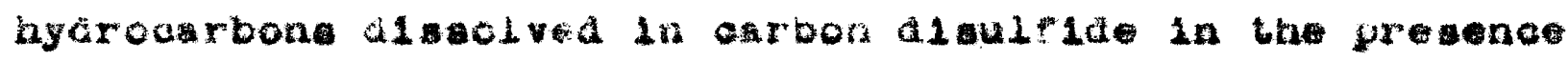

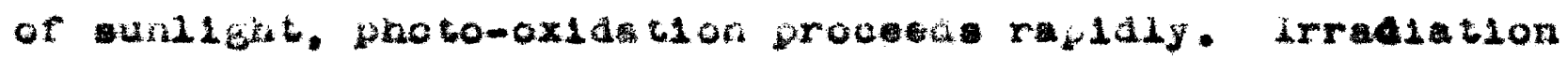

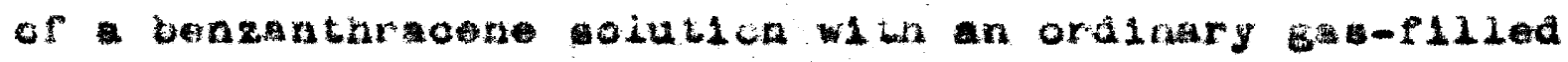
1nap too produced the photo-oxide. The poroxide of $9.10-$ 


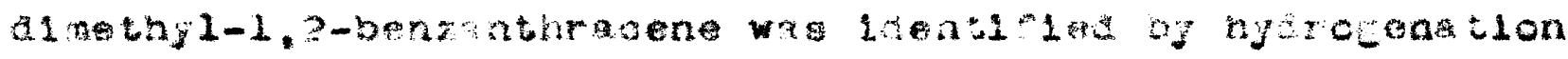

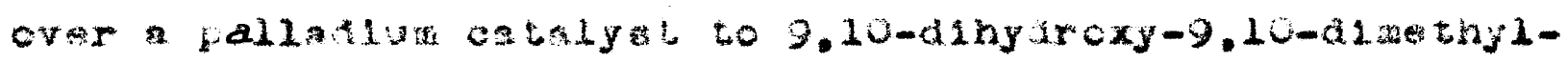
9.10-3hydro-1.2-benzm enracene.

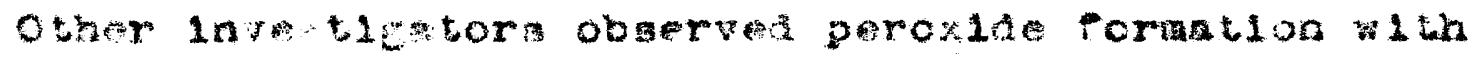
ompoung of this ty and they onoounterea preat alfi-

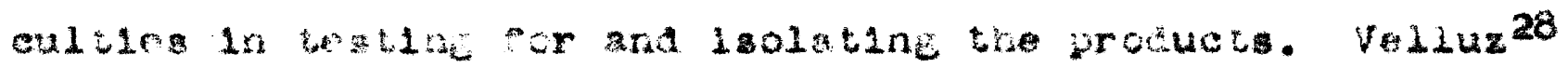
round thet $3,10-d 1$ weny $1-1,2-b e n z a n t h r$ cene and $1,2,3,4-$

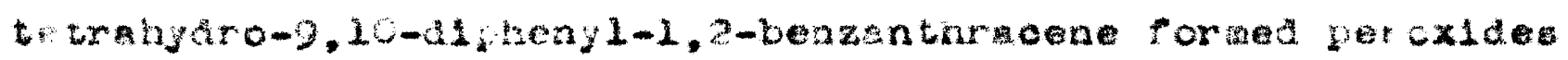

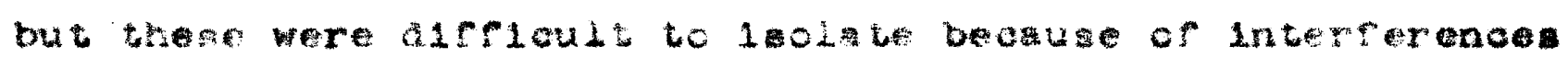

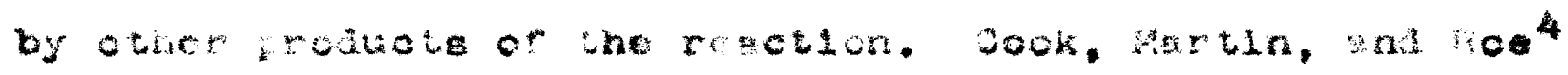

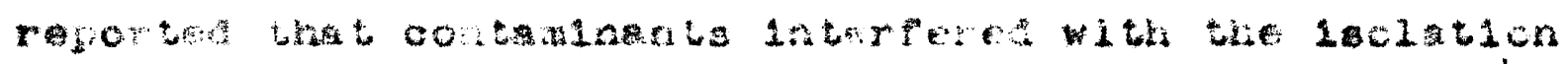

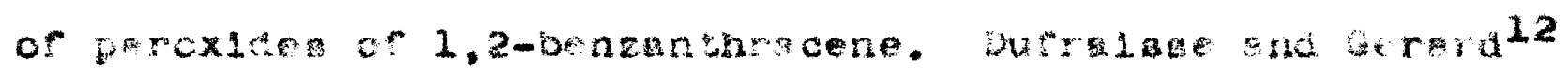

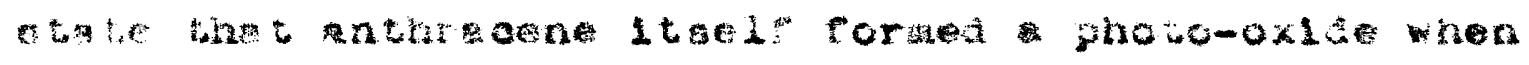

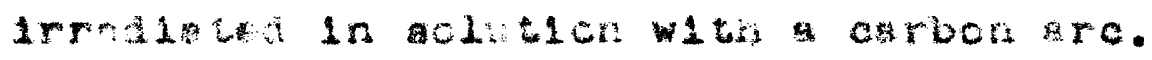

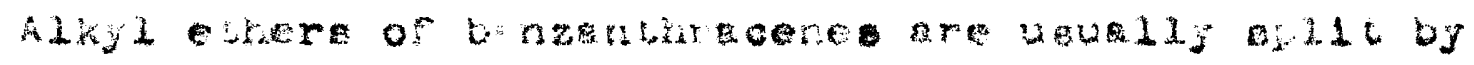

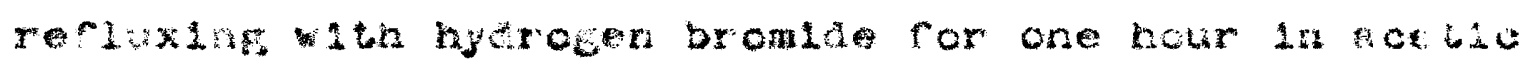

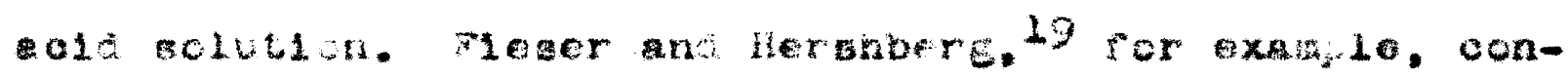
vertex 3-metiloxy-10-methy 1-1,2-benzanthroene to the corregondan benzaturci in thl way. In contrat to

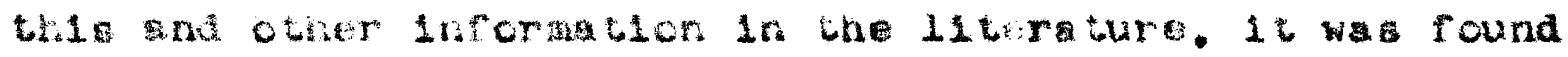
thet both methox compcume (VI) aro (Vt A) were ayt

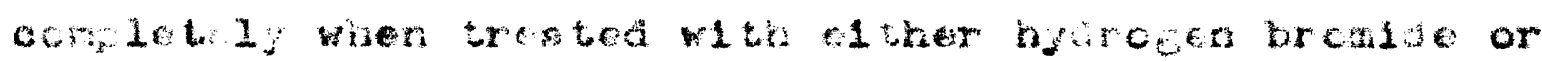

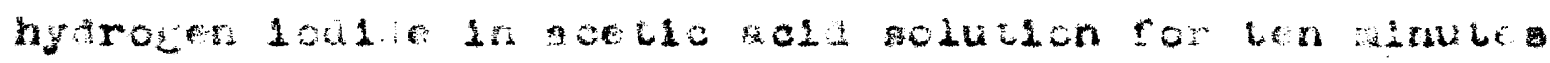

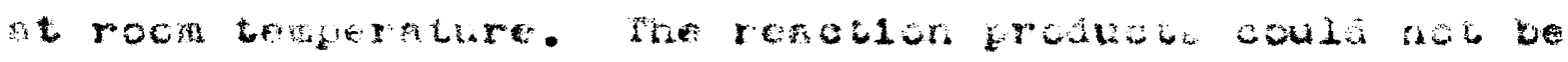

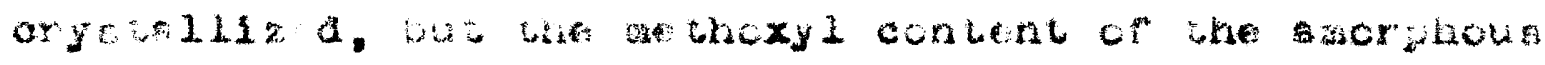

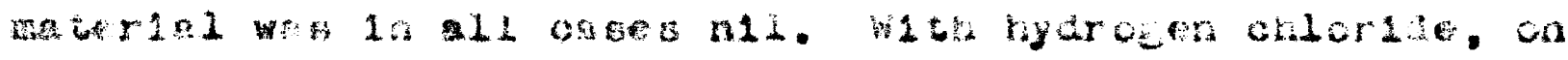


the other hand, only partial resotion ooourred in one hour at elther roca or reflux temperature.

Tre prislouly wentioned reaulta of the carbon and hydropen ansiysea of the reaction product ougke ted that In adaltion to olesvage of the ther group wo mecondary transtoration wa taking place. It wa hoped that the ultra-violet abeorbtion curve for tas raction profuct would Indioate whe had ocourrea. Thl ourve in elven in Figure 2 together with the ourve for the starting aterlal (V1). The curve for the thoxydinethyl-benzanthracene 1. Wry almilar to thet found for 9.10-a1methyl-1,2-benzantinracene ${ }^{21}$ as wa to be expected. It wa also to be expected that the curve ror the protuct obtained rrois

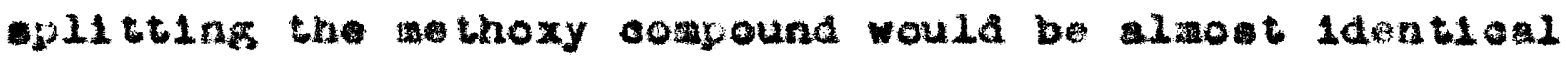
wh the ourve for the thoxy cospound 1tale. It is obvioug fron 1 gure 2, however, that the aborotion durva

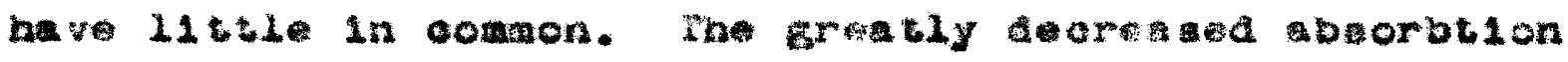
by the product frow the eplittlog of tho the thexy conpound

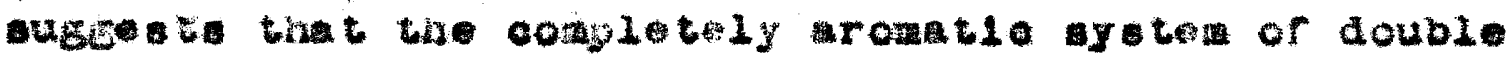
botwa ha been dostroyed. The probabllity of the formation or ptroxide wa discused abov and when peroxlde are forsed from thl tyo of compound, the aromtio eysten of

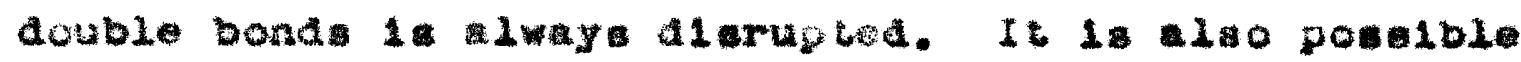
that the hyarogen lodide used to aplit the other coused myarozenation of the double bond the 3,4-poltion to

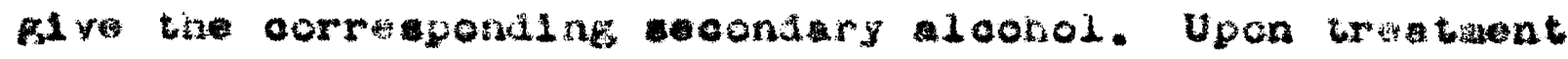
of the raction product it tí palladiu-carbon at $200^{\circ}$. 


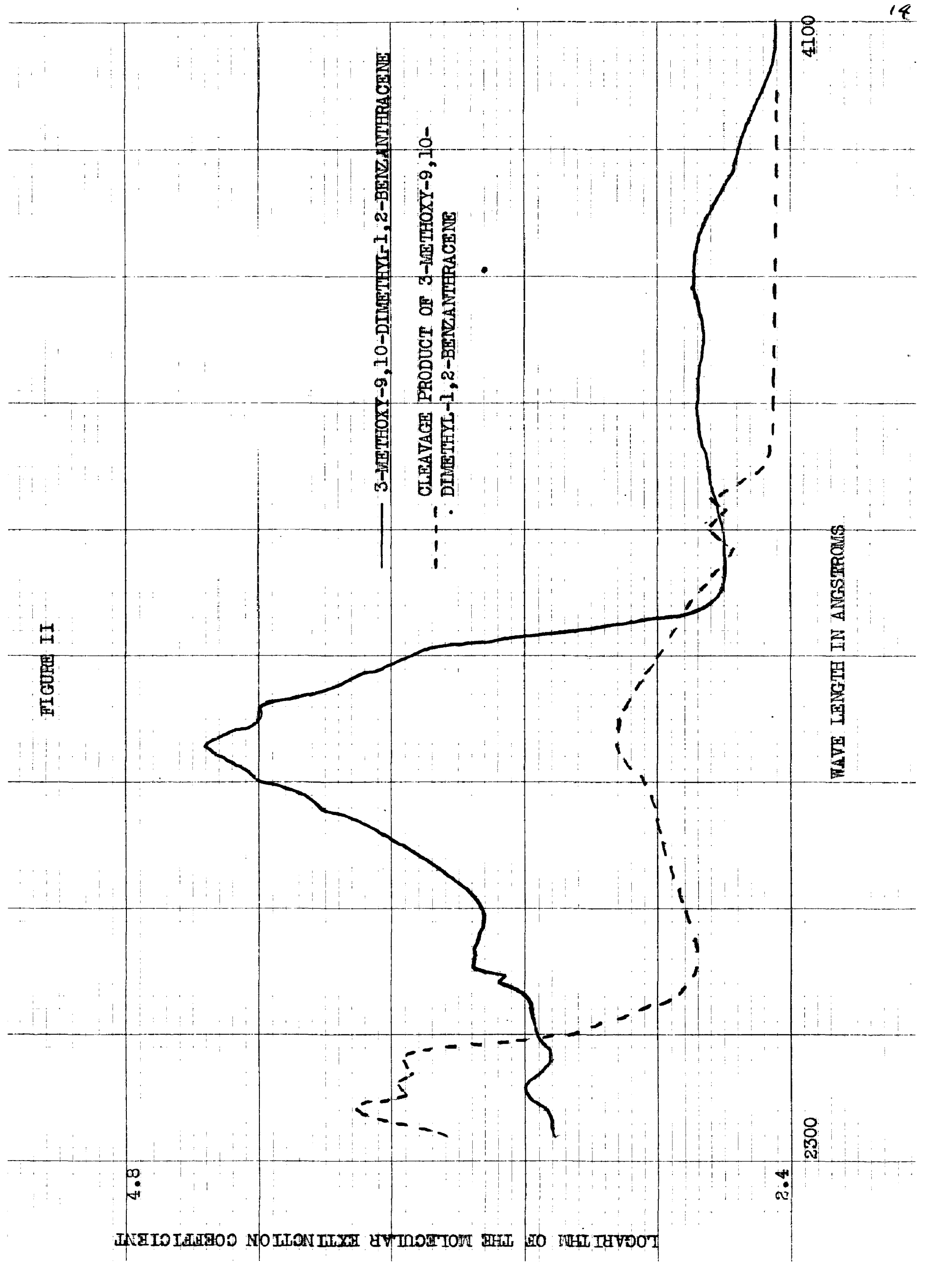


come evidence or denyaregenation wa obthined. The desred benzanthrol (VII) oould not, however, be lsolated a preduct of the dehyarozenation ronotion.

A sucoeseful procedure for ajltbing the thers (VI) and (VI A) wa Clnally developed in whloh pure dloxane was used a the solvent in place of flacial scetic aold. The dioxane nust be free of aldehydes a snown by a netitive Bohtre' teet. A nitrogen ataophere was used and the deaving agent wa hyarogen bromlde. It wa round to bes daslrable to have a all anount of hydroquinont present s an ant1-oxidant. The reaction product was mot more stabl. when hydroqulnone was used and only under these conditions were erystalline producta laolated. wen the produot obtalned under the ocndthon wre, however. quite unatabla

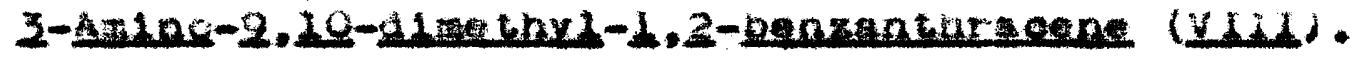
fine Bucherer regotion wa eaployed to oonvert the alaethyl Donzanthrol (VII) to the didhyldenzanthrylaralne (VIII). Inis conversion proved to bo almost a afficult a the eplitiling of the thoxy compound. Wo t of the alrficultie wh the isuchorer roation were later

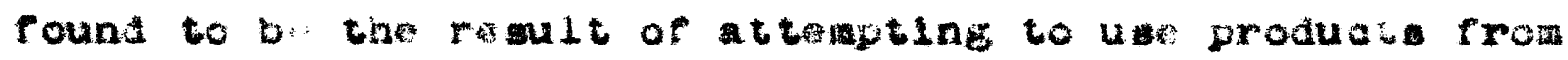
the allting of the thexy compound whl on wero not the axpecte benzantixole (ViI) and (VIIA) but were sotualiy by-profuct a sulting frop oxtation or hydrogenation or

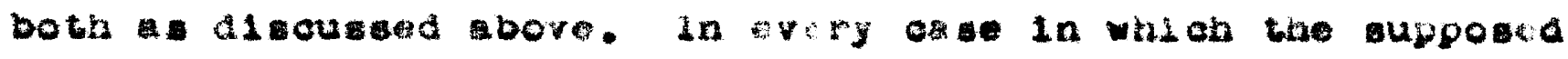
3-hydroxy-9,10-digethy 1-1,2-benzanthrao ne was 1001, ted 
a non-cryataline sol1d. the producta of the appliogtion or Suoharer ration conatione to this aclia fallod to

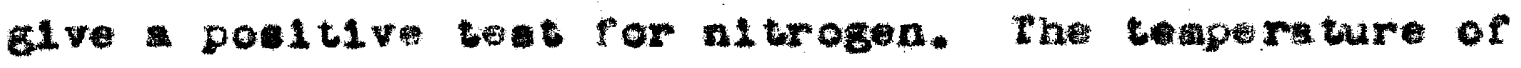
tha Suaherer ration wa varied rrom 125 to $250^{\circ}$ and the tive frem 12 to 60 noura, but in no os a wa any product obthined whah we soluble in allute hyarochlorio a a

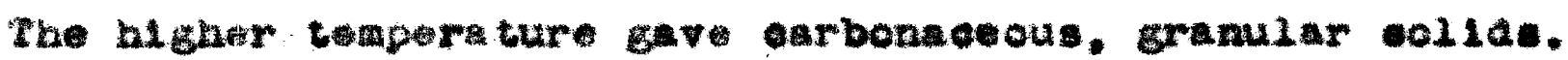
Sone of the banzene coluble oreanio reation produete

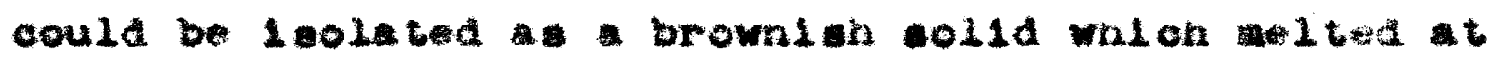

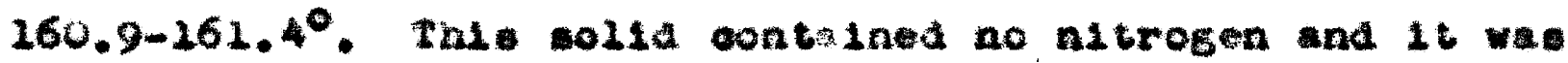
thought that poselbly it wa the diatthyl-bonzantarol (VII) although it wa not eoluble in gque ous alkali and wa only -paringly colubl in olalsen" alkall. When this oolda

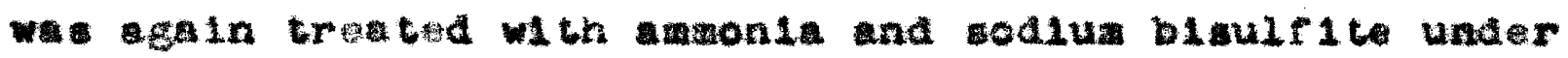
the conditione or the Buohorer rotion, no nitrogen could boteted in the product and it aould not bo converted to a at.

The pos 1b121ty that the product obtalned upon clearage of the 2 athy lathoxy-bonzantbraeone (VI) wa a ketone or

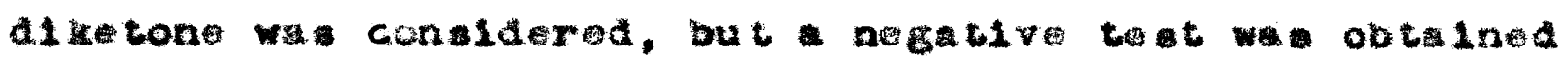

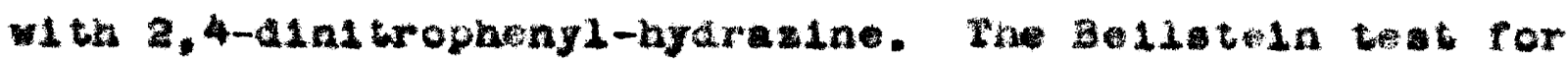
halogene and the brome watur toat for oldfinla double bonda wert both negatlve. An atloned above the peroxide

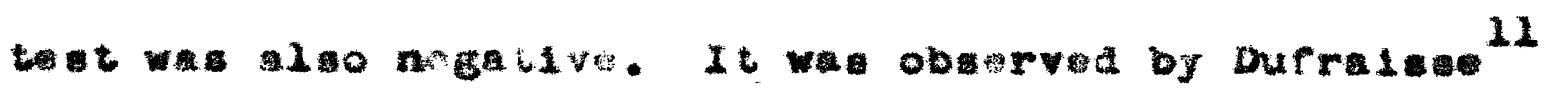
thit pexoxideg of anthraane wth hyarogen atom or aryl Eroupa in the weso poltiona rond11y lowe oxygen. Sinco

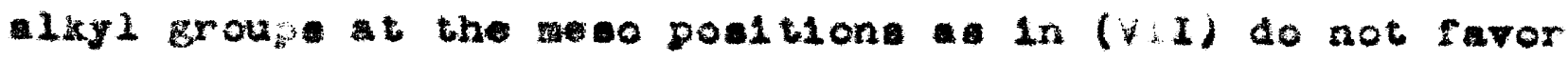


thl low of oxysen rron the peroxides. it may be dificult

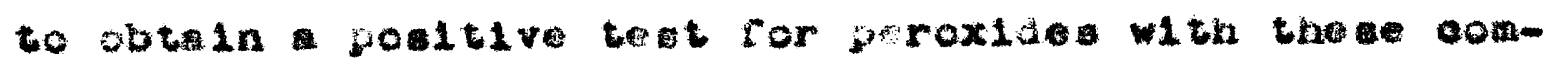
pound:

B2nce the thoxy benzanthrsoenos (VI) and (VI A)

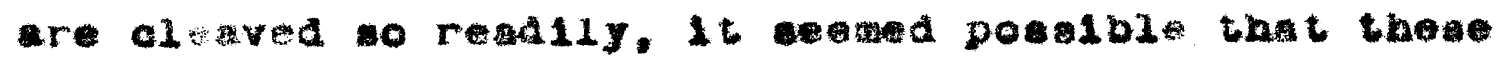

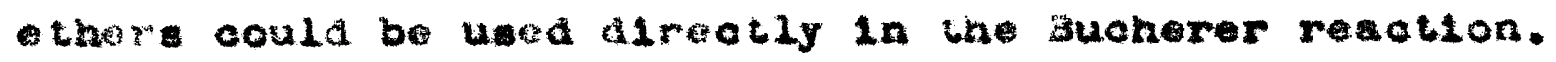

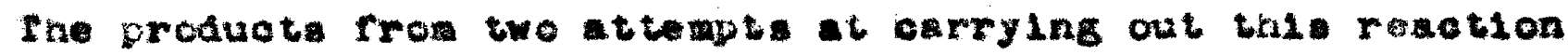
contained no nitrogen.

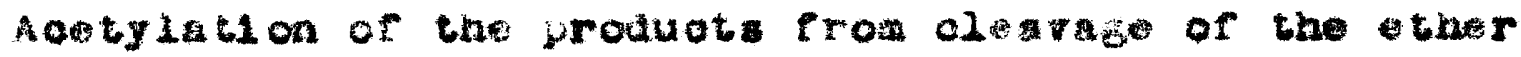
(V1) wa alsc triad in the hope that tho acotate alght be used 1ricty in the Bucherer reation. The product from

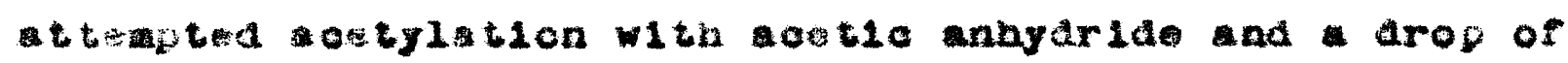

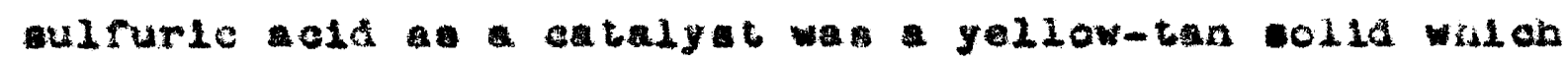

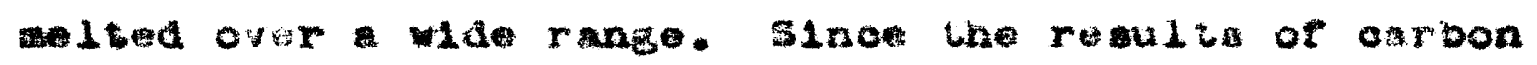
and hydrogen analyelo of this materlal were alo widely different from the value calculated for the dulres acotate. thle aprouoh was abindoned.

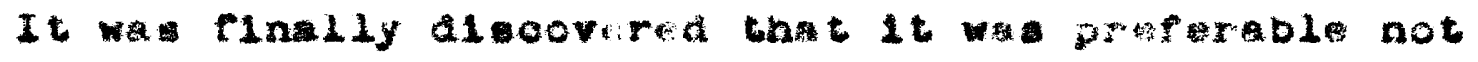
to tom to talate the pure oryakiline almethyl benz-

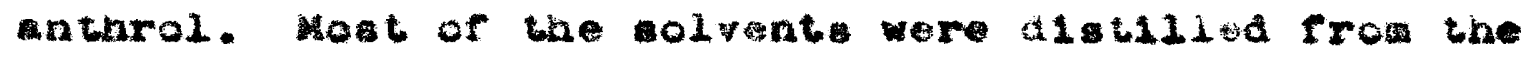
raction ixture obtalned in the old age of tise thoxy eompound (VY) a denerlbed above. The Green oll remalned

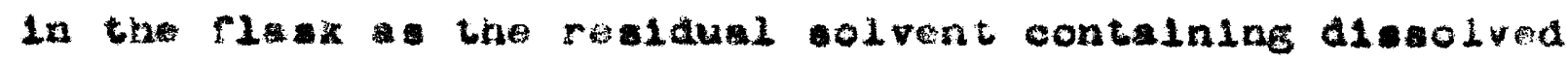
bydroquinone was decanted. Inl orude produat wa diasolva

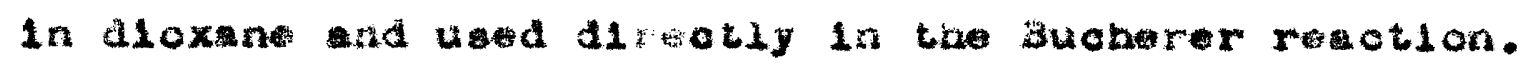

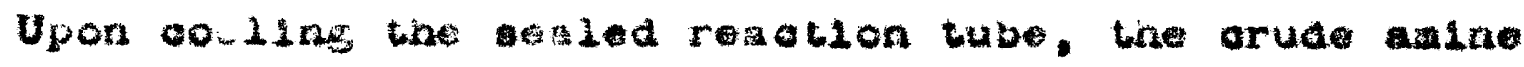

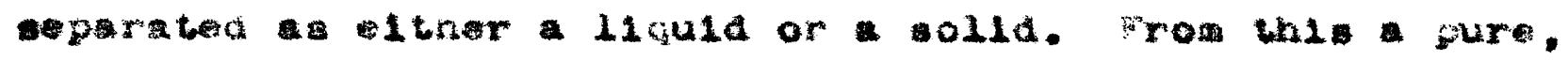


arystiline jrofuet wa obtained. The yleld oalculated erom the methoxy compound (VI) wa 67\%.

The sulfate (VIII D) of this ande va proparod a a derlvative. When allut alconolio solution of eulfurlo celd wa aded to an therel solution of the atune, the wine eulfate oryatilinad out lmodilately.

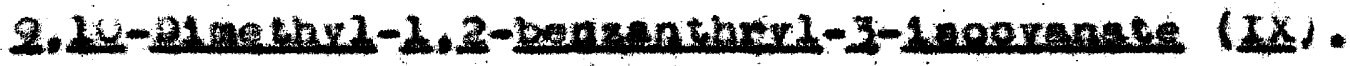

Hila laooyanate coula be prepared froul elther the orude Buaborer roction product or frow the puro, rearatallized ating (VIII). A elution of phosgone in toluene wa ded to a glution of the ame in other. Ine produet (IX) laolated by oryetallization from mlxture of tolueno and perroleua ther wa obtalned in 68 j jeld caloulated frow the thoxy comound $(V /)$

In orger to stablish the laentlty of the leooyanate norw completely, it wa convrta to the urathane. Thle

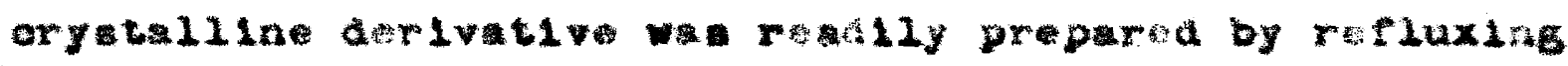
a solution of the laooynate in bostute alconol.

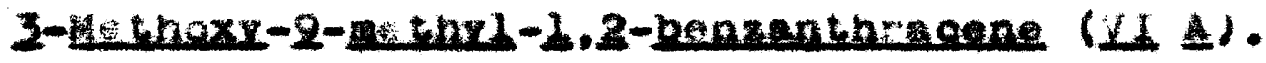

This compound wade from the orude anthrone (iv) La the aluycroanthranol ( A). The anthranol wa propared

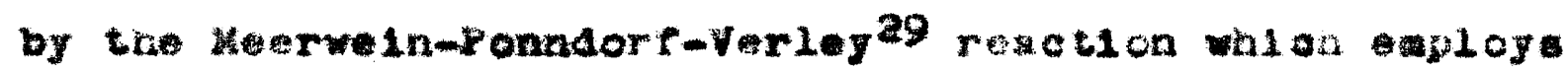
-1uminur leopropoxide in leopropyl aloohol as the raduolns agent. A. with the unalagoua alathyl oopound (V). It was Imposible to obta in the proutot in pure. eryetalline

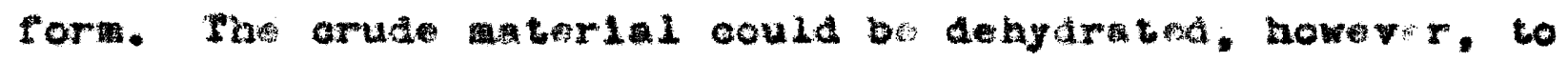

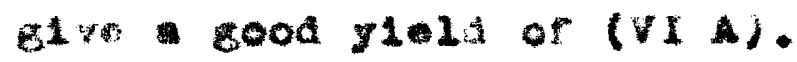


Dehyaretion or the secendary alcohol ( $(A)$ could be earriat out by heating $200^{\circ}$ on the hot plate deoribed

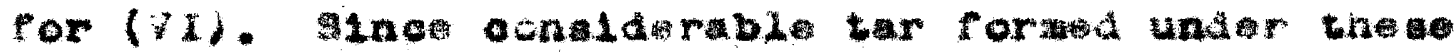
conditlons, an 1mprove thod we dovelopad. Artr the completion of the reduction with luminua laopropoxide. wot of the volatile material wa aletilied ofr and ralaced w1 th xylene. The mixture wa refluxed for one-half hour and then diat1lietion was renawed. Dehydretion ooourred and a the wate formed it wa removed azeotropleally with the xylune. Inle thod allalnowe the darger or overhesting. A 67\% ylela, oalcilated rrow (III), or pure, whit plate was obtalned.

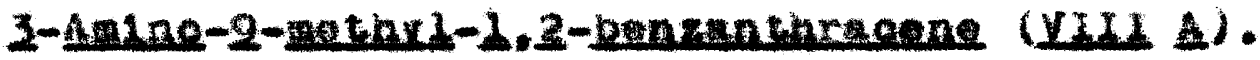

The thoxy compound (VI A) was oplit in exacty the

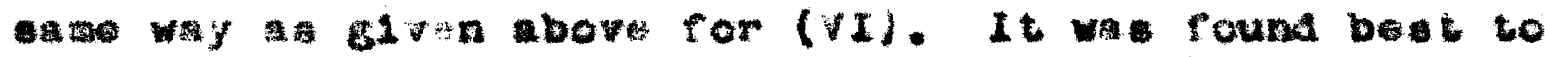
trat only two grom of matoriat at a time in order to keep decomposition to minializa.

The erude aethylbenzantirol (VII A) wh usend wibout purifisation for the prepartion of the alnowthyl benzanthreone (VIII A) by the Bucharar reation provioualy Aosaribat for the malogous eopound (Vill). The glela of pur1fled anine wa 646, calould ted from (VI A), whlle the

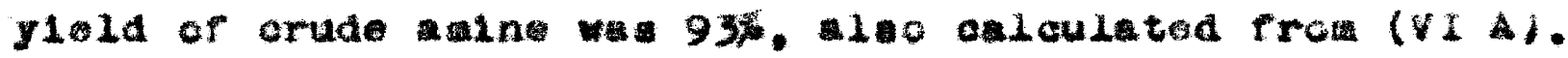
The crude aterlal gave good yleld of the loodgante.

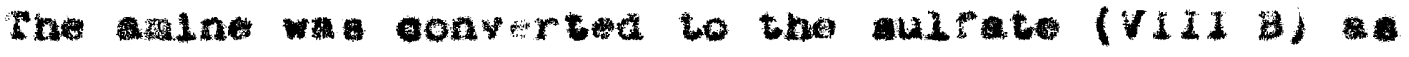
a. sariovd bove for (VIII).

From some of the tucherer reaction maturge there we 


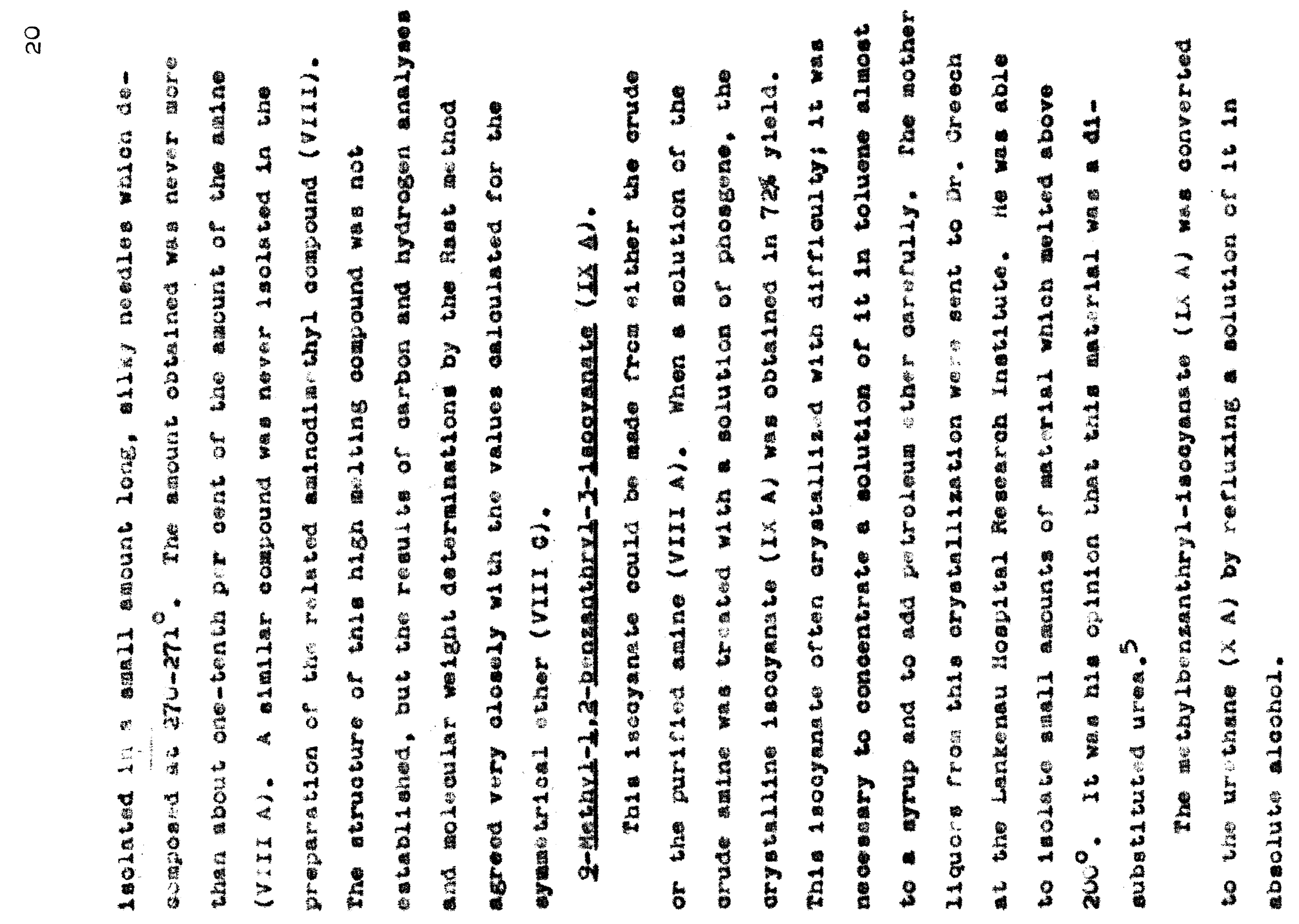




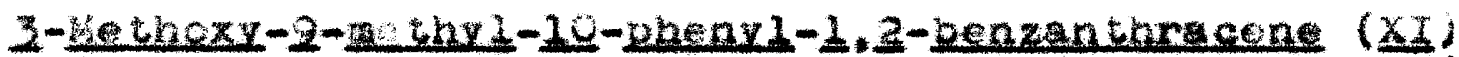

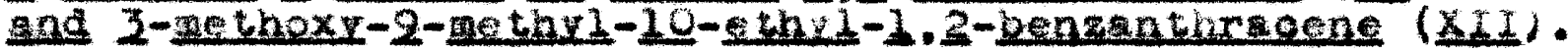
In oraer to uemons trate whe vratility or the anchrone

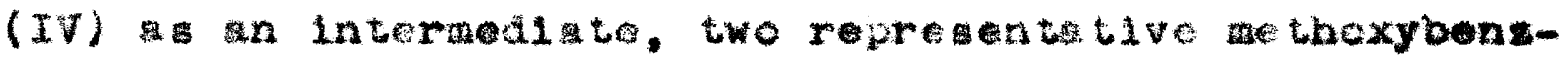

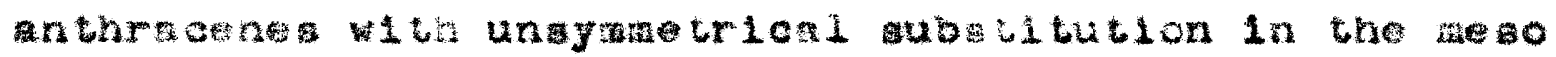

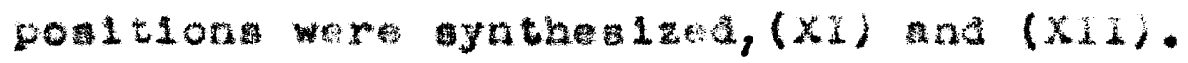

The 10-pheny 1 comound ( $X 1$, was propared by the action

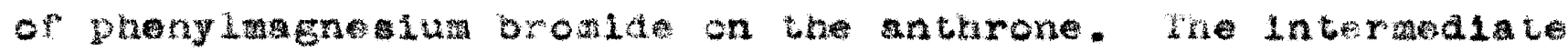

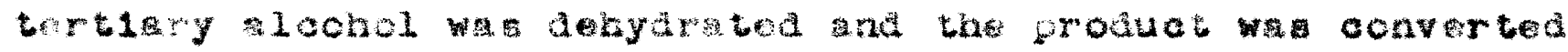

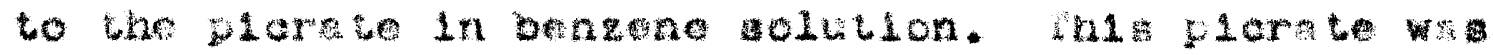

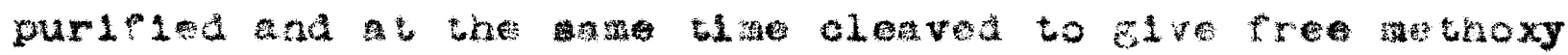

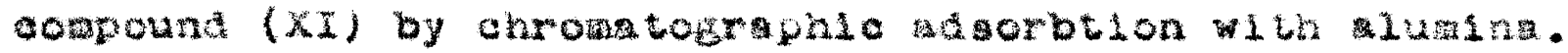

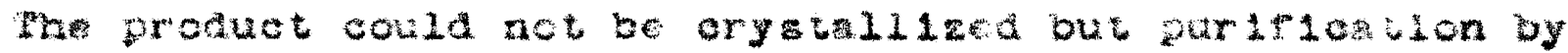

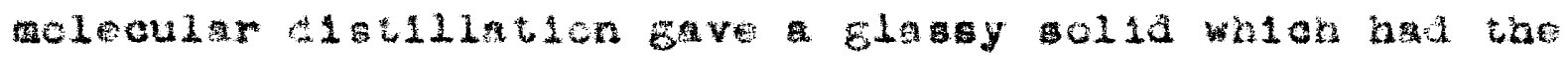

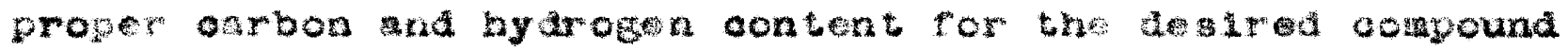

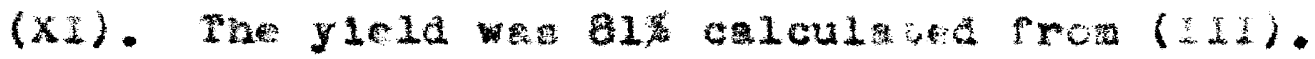

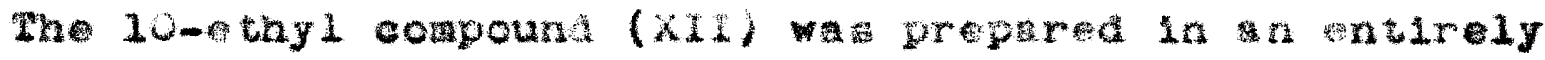

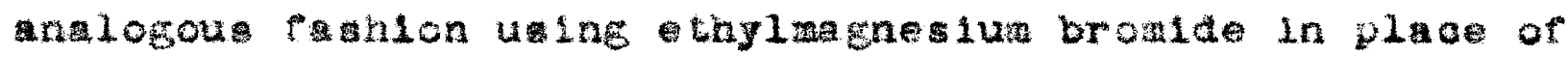

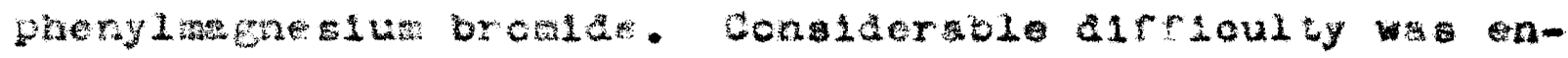

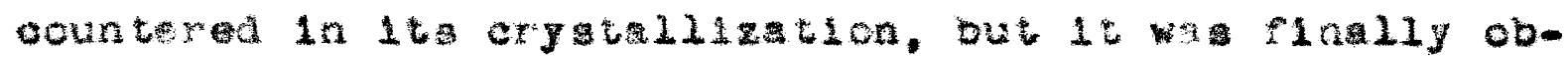

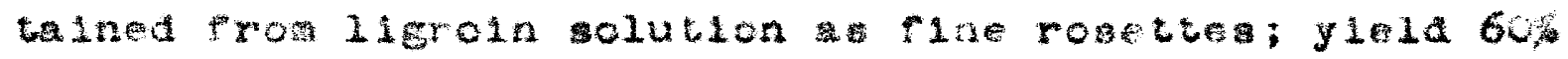
onoulata eron $(2 x)$

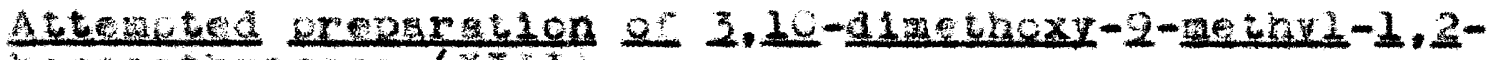
bonzanumpeane (XILI).

The crude antarone was alsoclved in bylatne: chlo

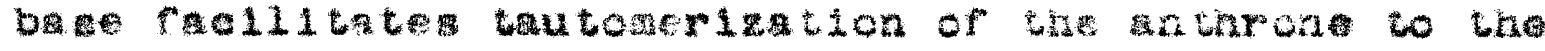

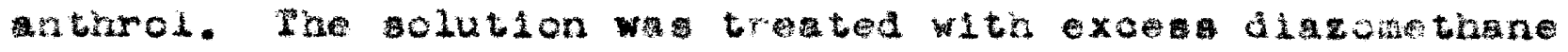

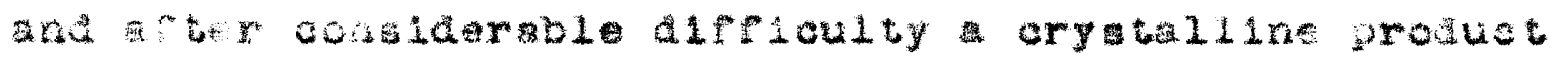

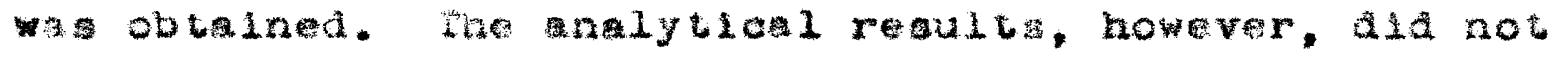




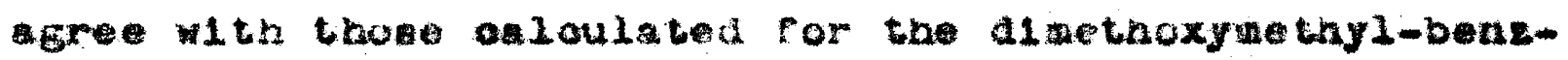
anthraene (XIII).

Aocording to the analytionl rowlte the produot had

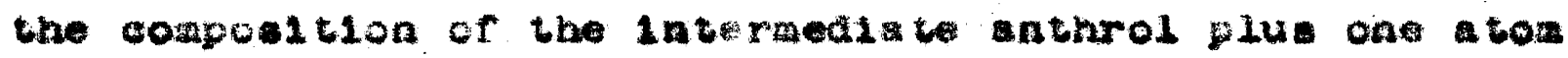
or oxygen. It appera that peroxido may have boen formed. Aocoralas to the worke of Jullan and cole. 22 hoveva. the poroxide obtalned frow the anthrol voula be expected to concain two daltonal atome of oxyban inatoda of only one. It appere. ther rore, to be 1mposelole frow the

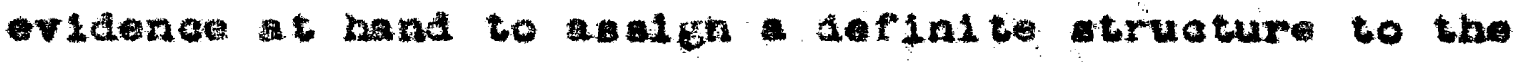
compuna obtainea nere. 


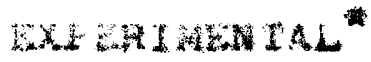

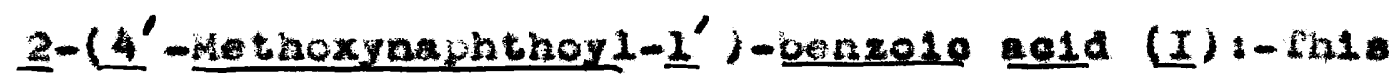

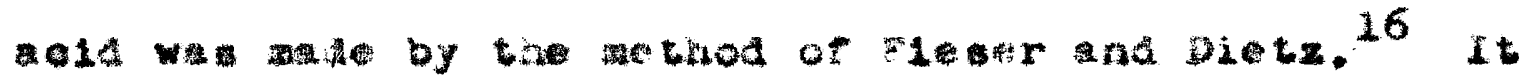
wa round that by keplng the temprature at $15-20^{\circ}$ aurinf the adition of the aluminum onlorlde, the yleld wa in-

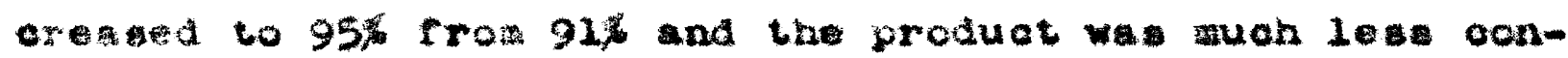

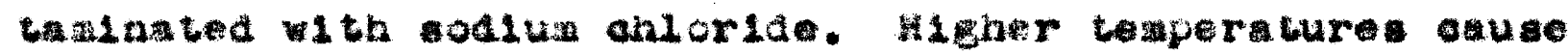
grenter darkening of the protuet and ake 1 ta purifieation more alficult.

Four munared gran of aluminut chlorldo wa adad in axall portione orer perlod of bout one hour to a colut1on of 234 E. (1.48 moles) of $\alpha$-tethoxymaphthalene and 234 . (1.58 aloe) of phthlis anydriat in 1200 . of tetrachloroethane. Fhe teugerature wa kept below $20^{\circ}$ by atrring vigorouty in an loe bath. Heter the adition

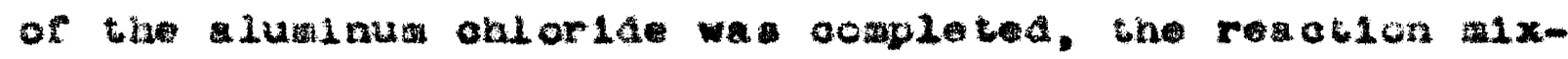

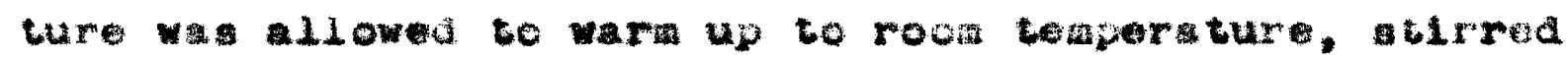

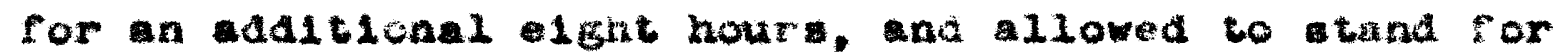
twenty hours. Arter deoompoition of the oodplex 1 th hydrochloria acid and 10 , the tetrachloroechane wa rewoved by etcan diet111ation. The brown, granular acd wa sitered of and alsacivad in aqueoue alsall crow which the sodiun at cryetallized on coollat. rurifieation

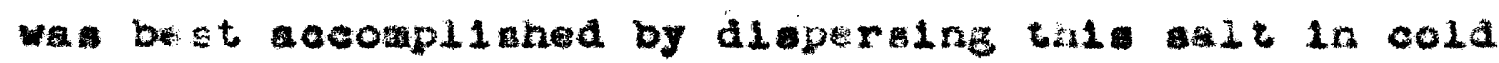

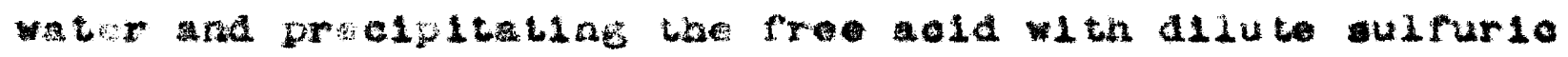


selat the prolpltato wa wahed thoroughly with rery allute ald and then with water. The produot mut be arerully dried in vacum oven allowing the temperature to rlae erom $35^{\circ}$ to $105^{\circ}$ a the prook prodeda. If rurther pur1flation 1 raquired, the sald may be convitiod to the

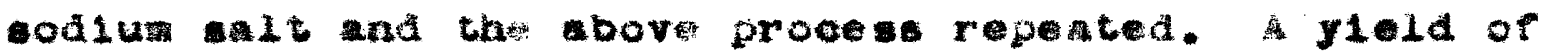
431.6 6. (95\%) of a wht flocculent powder was obtalned: $.0 .196 .5-197.0^{\circ}$

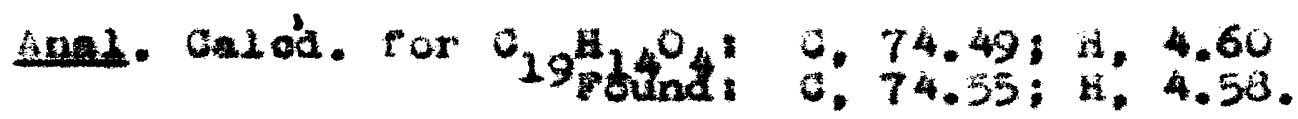

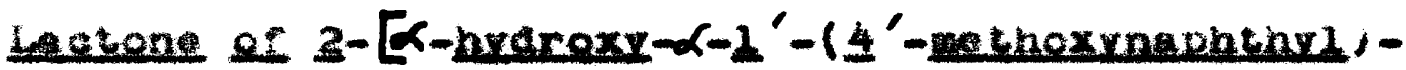

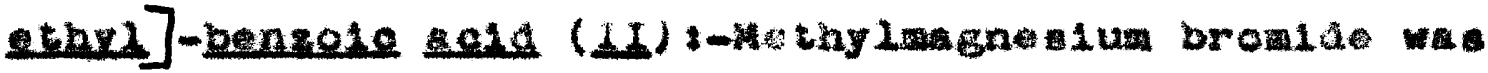

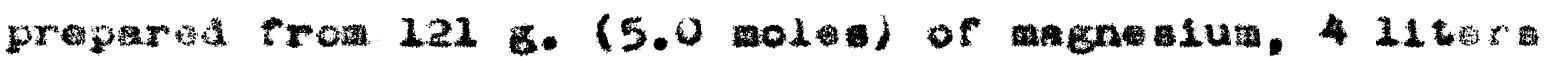
of anhydroue ther. and in exceas of sethyl bromide. The sclutlon was fltorad in altrogen tmoshero through a cotton plac to remort troe of magne lua and adulthed

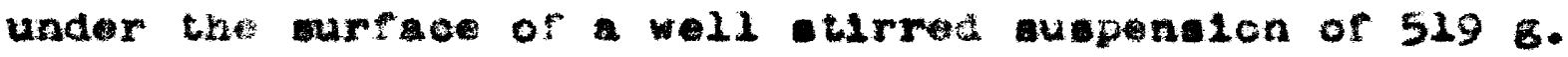

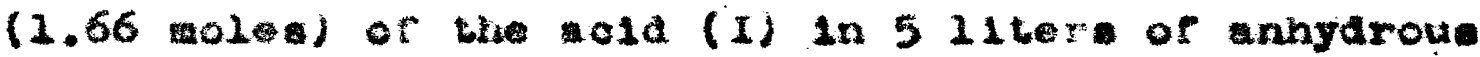
toluene. A okalky yellov olor appored waloh changed to greenlah-yellow, orange, and rinally to a mady yellow or red. The final color varied from preparaton to preparetion, but wost often 16 was auddy yellow. The renclon

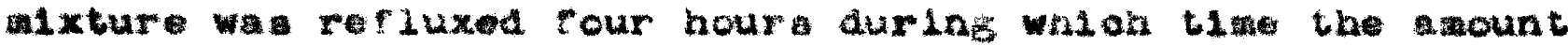

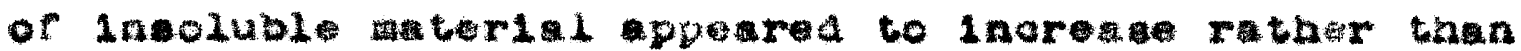

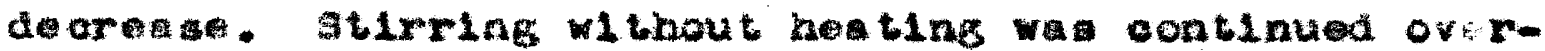

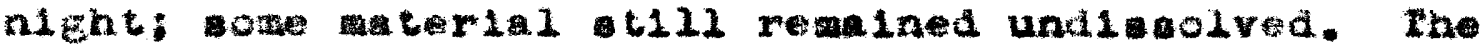
complex was deoomposed wth loe and hydrochloric acld and

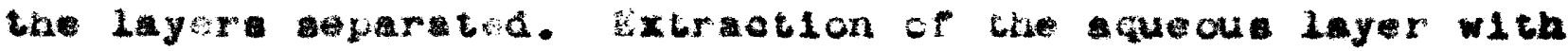


benzene-ether $(2: 1)$ wa contlnued un 11 the extrat wa: colorlean. These atrects wor added to tho orlglnal nonaqueous layer and the combined solution wa wahed with aque ou sodlut oarbonate unt11 the weshinge, whion originaliy wer blood-red, wer no longer colored. After wanlng with enturated odiun chlorla colution, the organlo layer wa arled over magnesium sulfte. The solvent was reaved by dit11lation under reduced prosure until the red, ayrupy lactone in sanli mount of toluens remalned and further

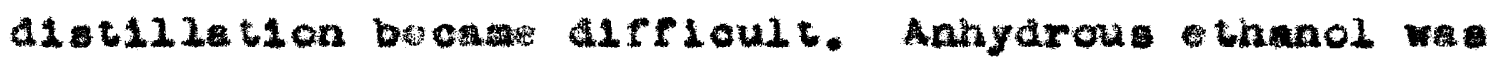
sded in an ancunt gul to one-fourth the voluae of the conoontrated lactone. Eetroloum ethor $\left(30-60^{\circ}\right)$ wa then aded until a fat throldity ap earod. onlliling in an 10 bath prespltated $286 \mathrm{~g}$. $(57 \%)$ of yellow-whlte powdery produot. 0ooling and concentrating the mother 11 quor did not oause further orystallization or lactone. but by nolecular distiliation of the residue laft upon evaporation or the sclvents, an salitional $57 \mathrm{~g}$. of an

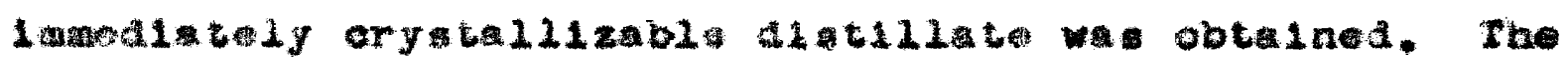
total ylela wa 343 f. or 7 .

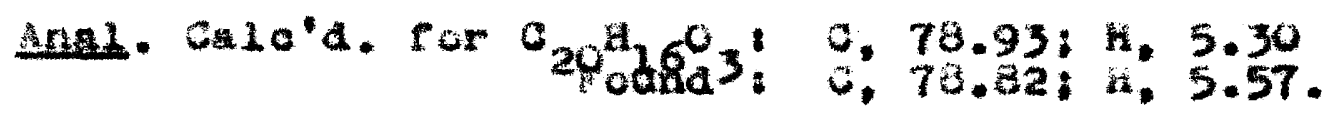

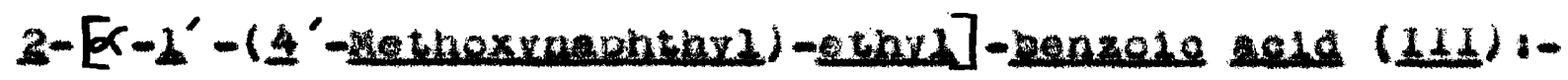
Hydrolysin and reduetion of the lactone (II) wlth alne and

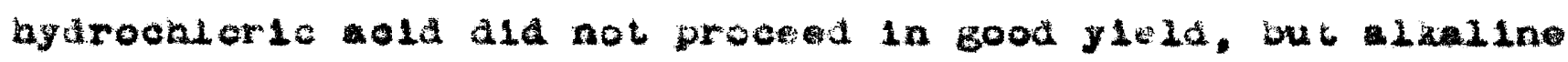
hyarolyals and reduotlea gavo an alacet guantltativo yleld of (III). Fo orange solution obtalned by dlesolving $363.8 \mathrm{~g}$. (1.19 mols) of the lactore in $8500 \mathrm{ml}$. of 956 alcohol was 


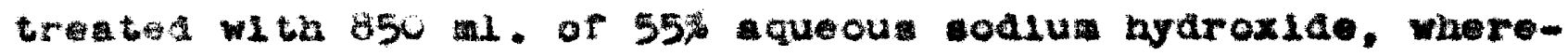
upon the oclor ohanged to a dep red or violet. The eolu-

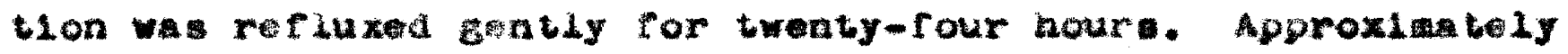

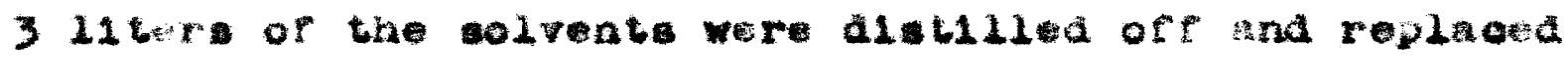
by uter; dietiliation wa then contlaued untll violeat

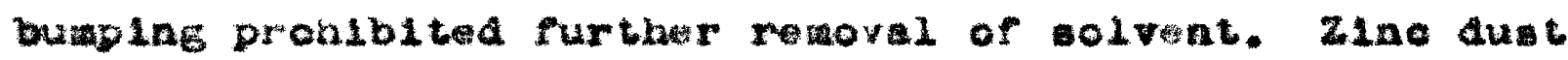
$(850 \mathrm{~g}$.$) atcivated by oopptar sultate. 1700$ al of 55 codlum hydroxide. and 4000 a. of water wer addod and the mxtur wa refluxed acond twenty-rour hours. The tray-

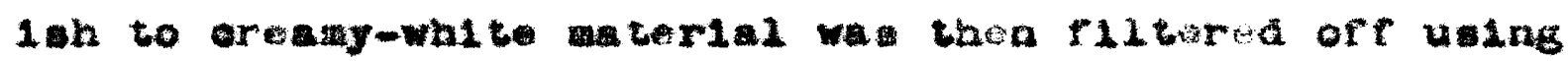

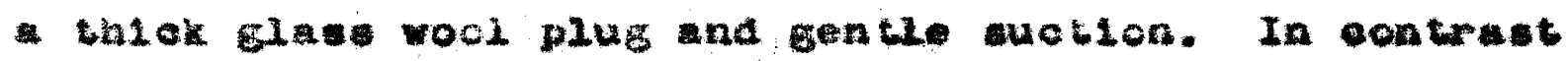
to Sewmen" procedure. coldiflation of the flicrate producer no solla alno the sodiua ant of the bubetituted bentolo acld wh ineoluble in alkall under the above oonditione. Phe precipltate in the pliter wa extratad by

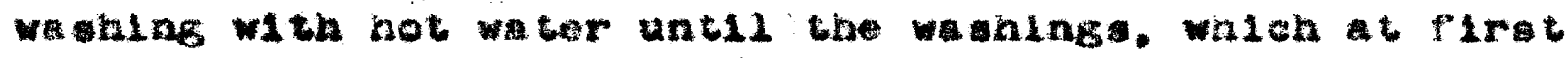

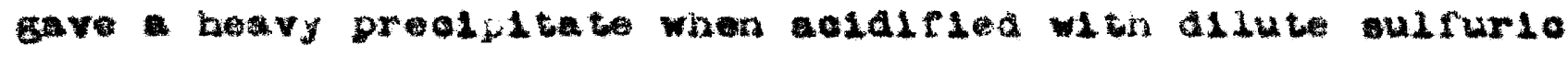

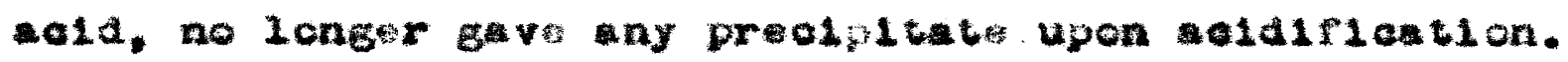

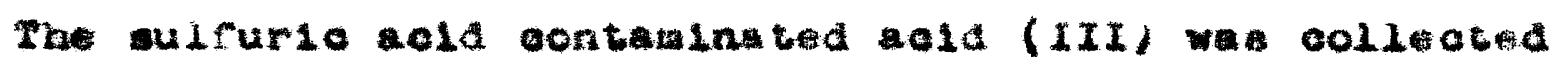

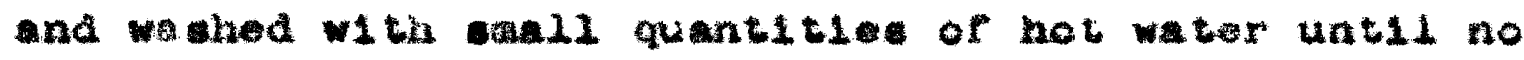
tot rot the avista ion wae obtained upon addition of barlun anlorlde to the wabirgs. The product was aried in - vacuua oven to not ore than $0^{\circ}$ unc11 almot all of the

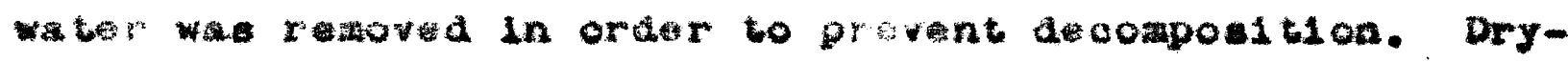
Ing was then eomplatad at $145^{\circ}$. A 93 y1eld (358 B.) of

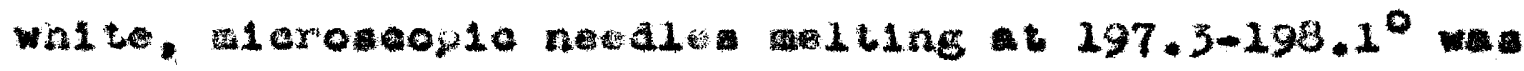
cotonat.

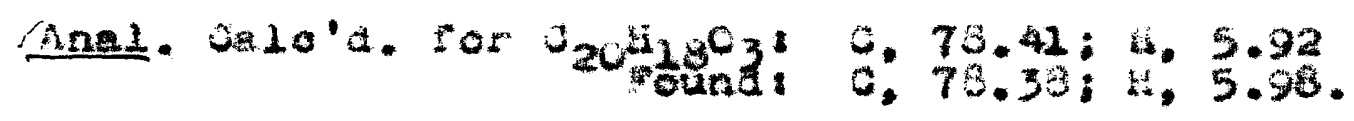


3-Methoxx-2-nethr1-1,2-benz-10-anthrone ( IV):-then $25 \mathrm{~g}$. (0.082 molos) of tiue subetiluted benzolo ac1d (III) wa trented in copher resel $\$ 1$ th 250 b. of anhydrou hydrorluorla cold oyclization proceedrd libout alfrleulty.

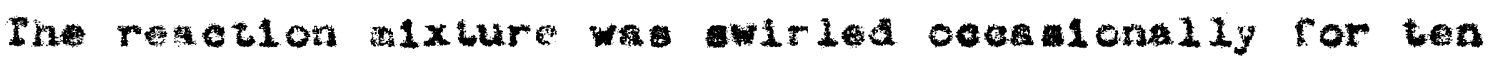

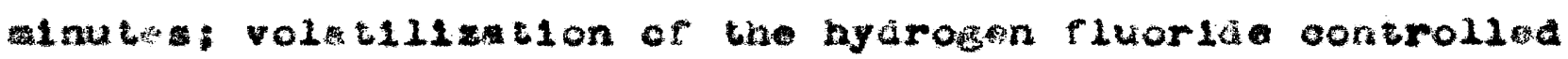
tho temperature. The dark red solution ws alowy adided

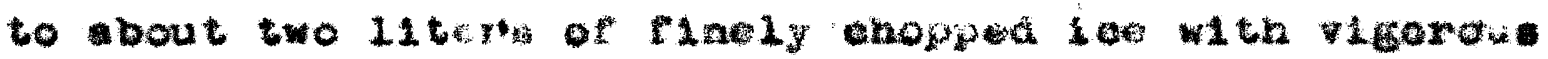

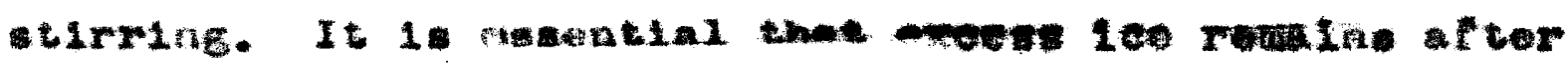
the adition 1 oogplete snoe surring wi Ch this 100 prevents the anthrone rrow foraing balls whah intertere with thorougi wahlag. The brownl ah, endy anthrone wa wahed rree of acid witn loe water. Alasolved in two 11 ters or bolling soetone and the aclution wa raplaly conowntrated.

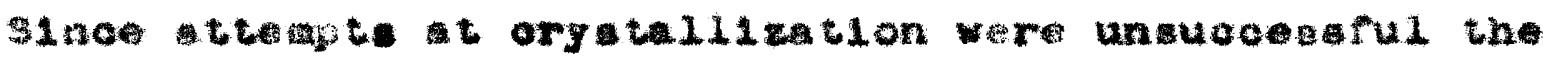
acetone was oompletely eraporated and the produot aried to conatant welght under reduoed preseure. Thl orude anthrone welgred 23.0 E. (93\% ylela). The proportion of 1mpurtitea present wh not deterained, but the orude enthrone wa

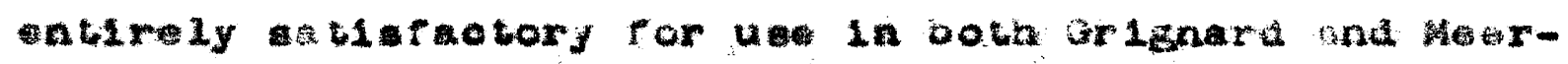
wein-Fonndore redions.

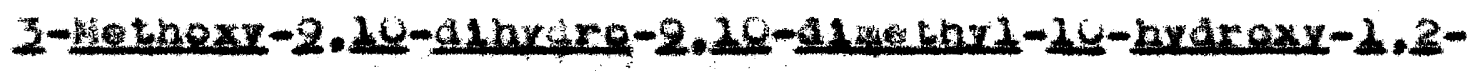

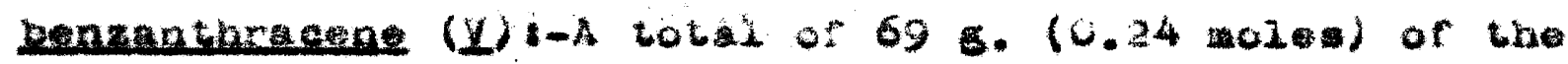
oruan anthroves wa disolved $1 \mathrm{n} 15 \mathrm{w}$ wh of benzene produclne cark red clution. Thls solution was slowly added to solution of mothylaggnealum bromide in 2400 m. anhycrou ther propared from $23.2 \mathrm{~g} .(0.956$ moles) of magneslum turnines, and an exanas or mothyt bromide. The 


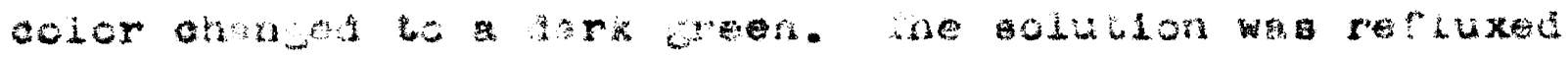

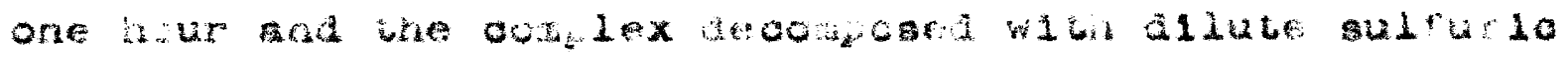

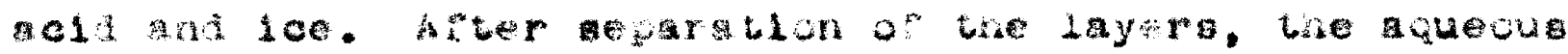

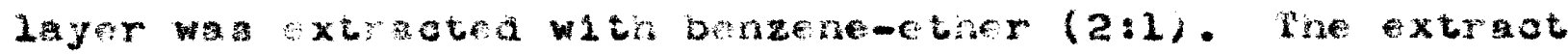
wa arad to tip orlelial non-aqueous layer and the com-

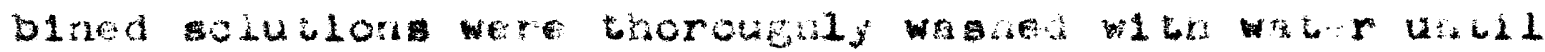

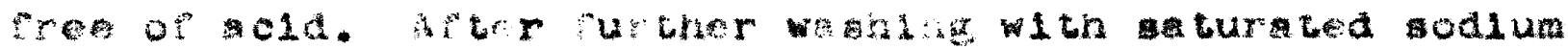

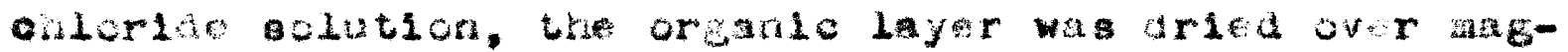

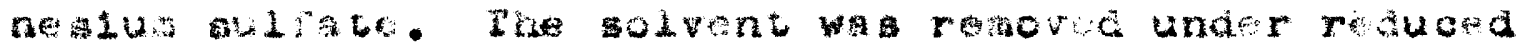

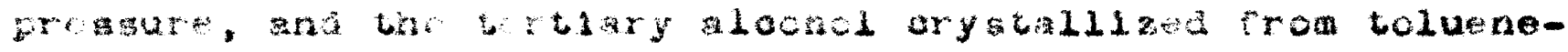

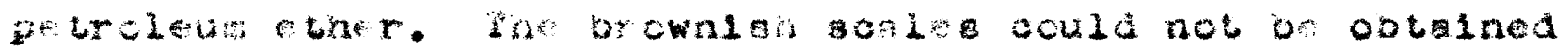

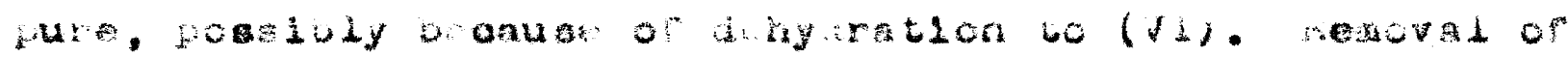

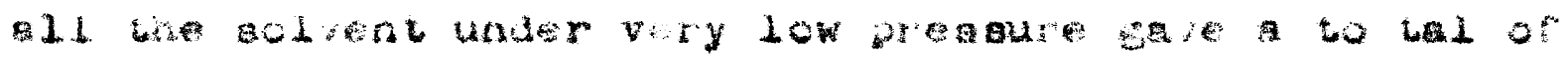

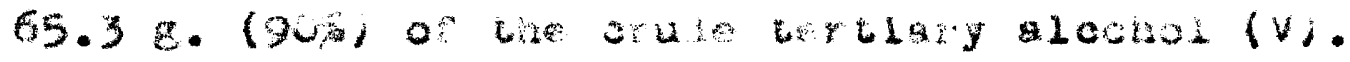

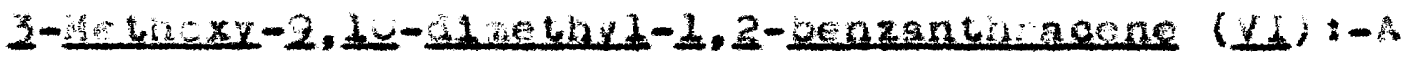

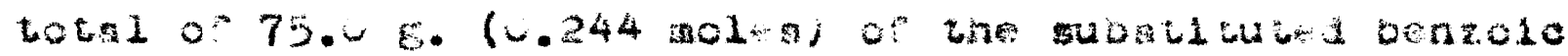

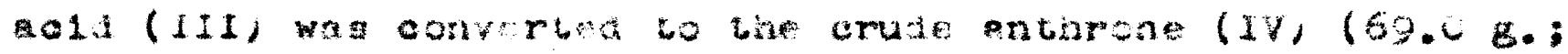

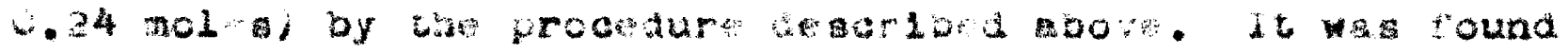

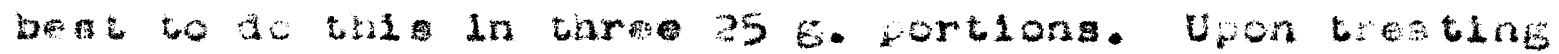

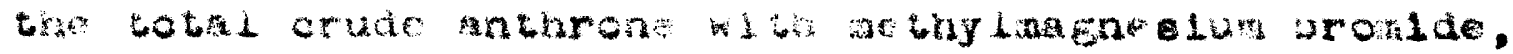

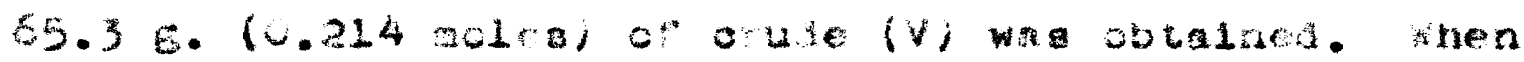

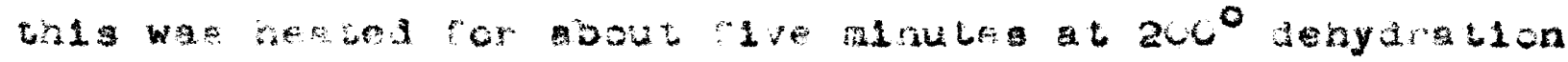

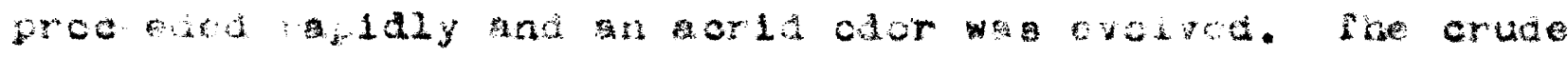

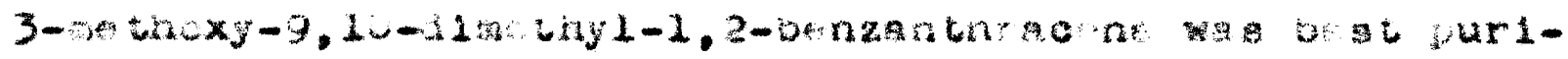

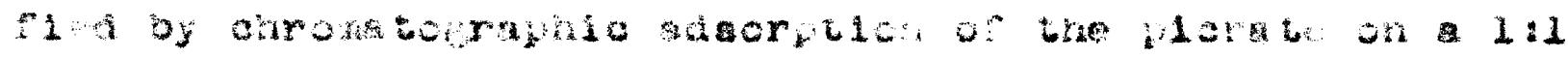

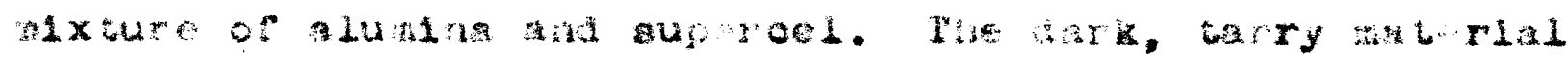

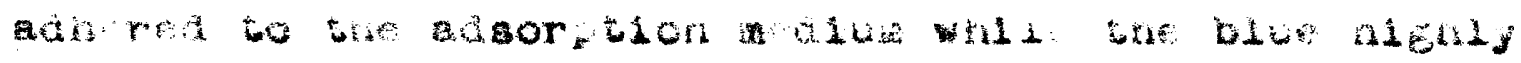




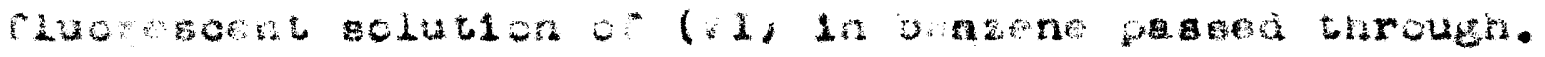

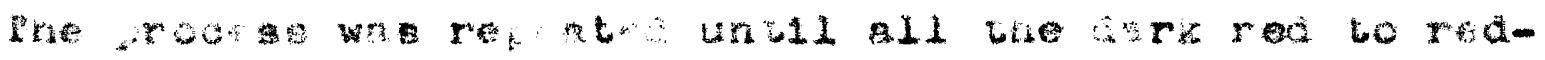

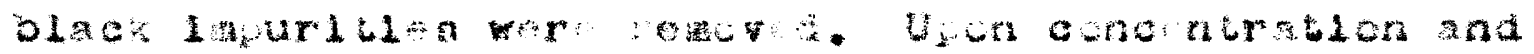

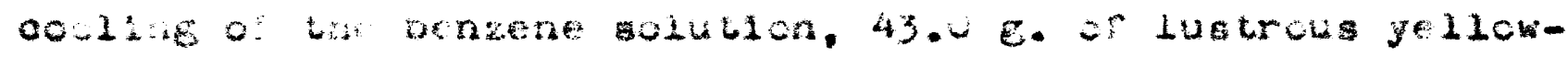

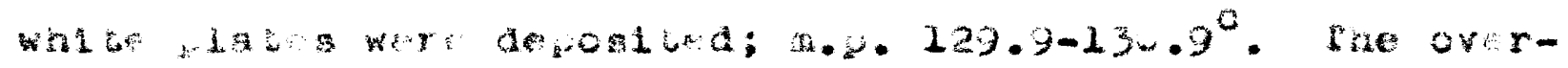

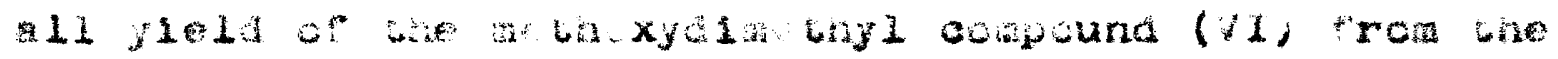

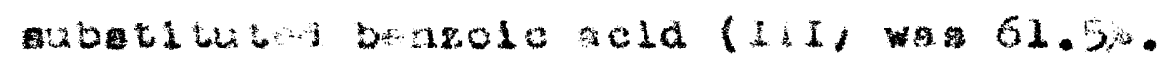

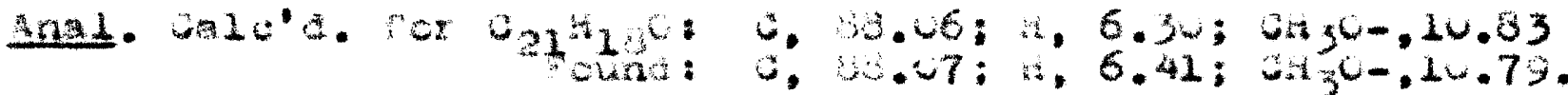

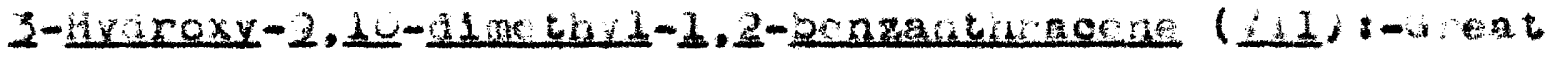

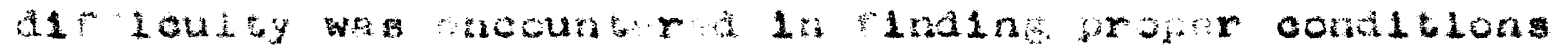

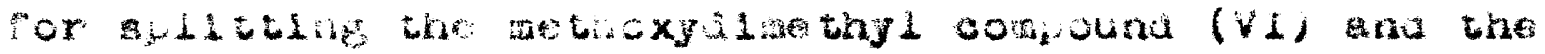

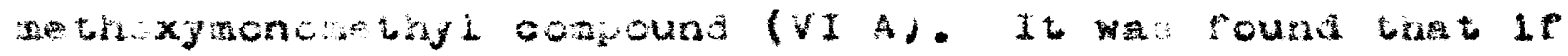

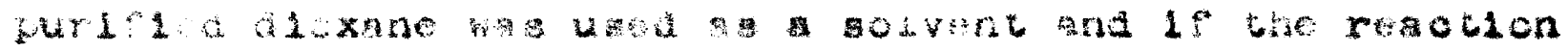

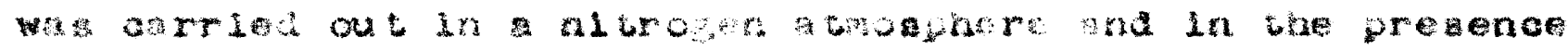

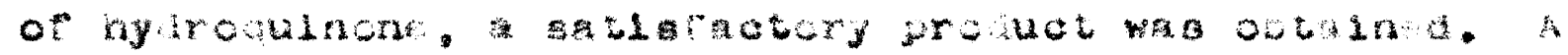

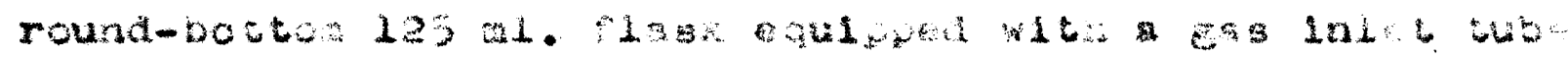

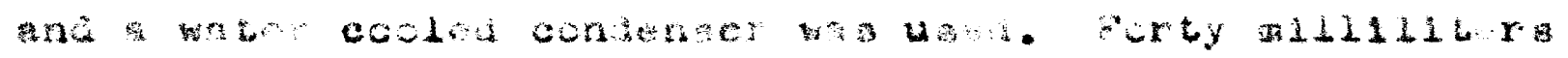

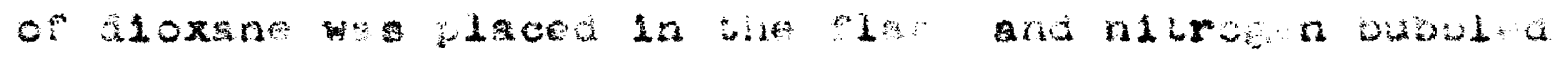

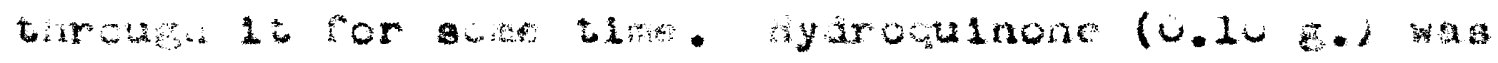

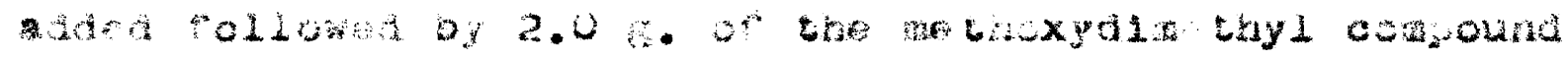

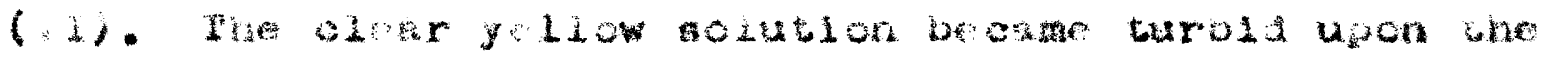

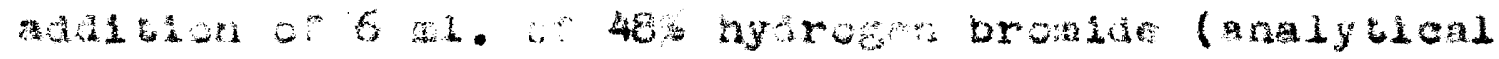

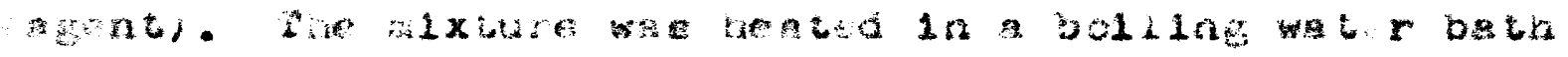

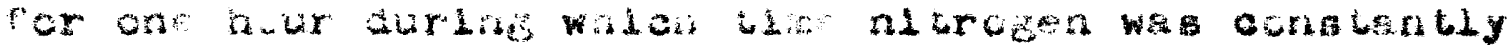

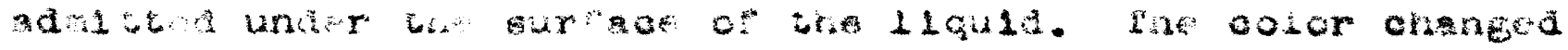

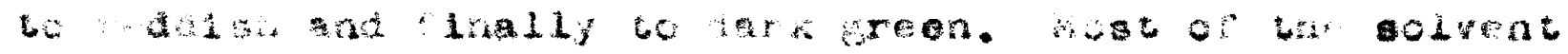

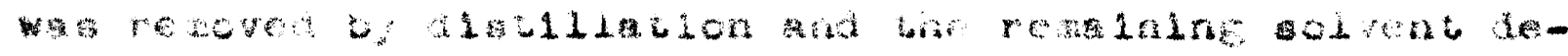




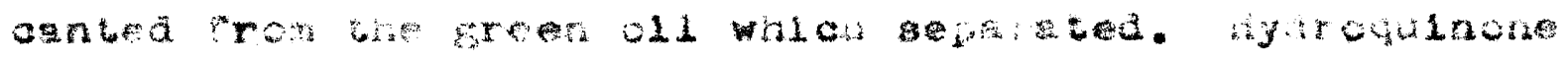

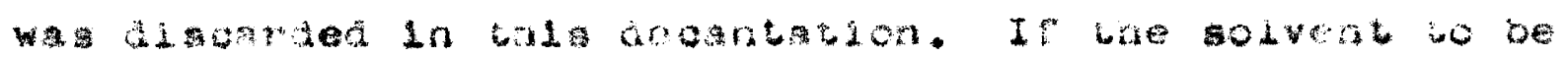

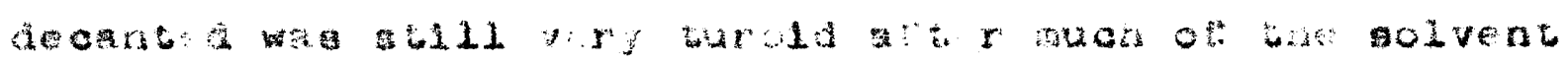

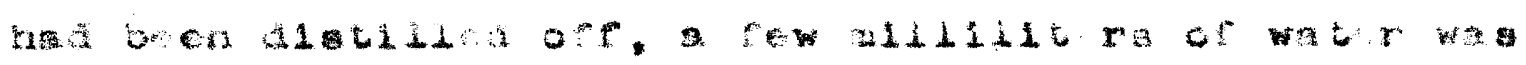

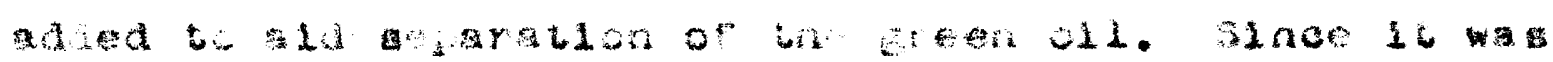

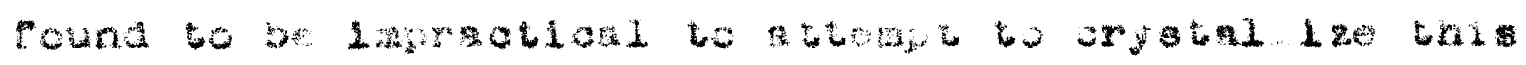

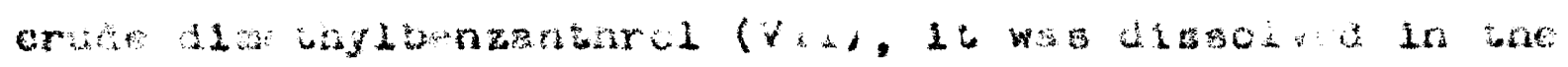

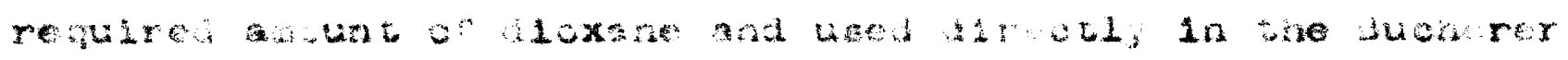
$\operatorname{retant} 10$

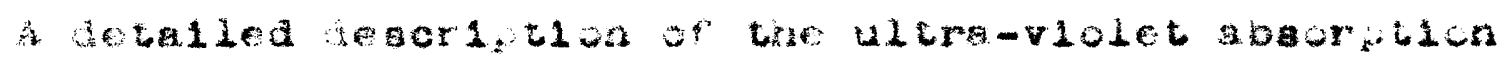

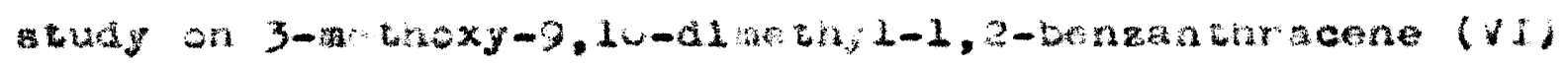

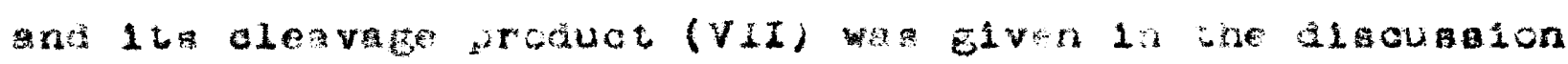
w.

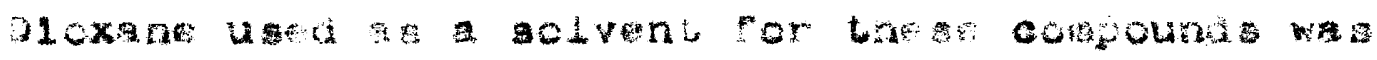

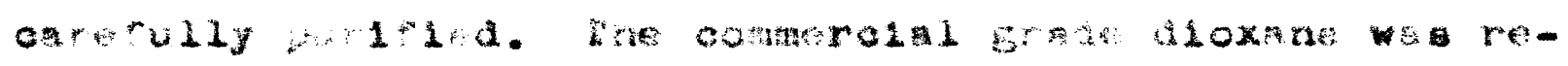

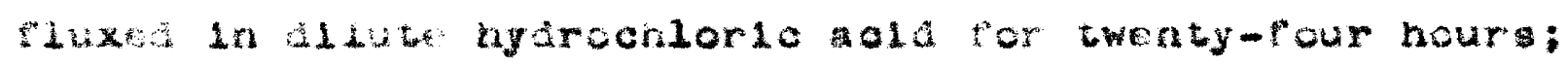

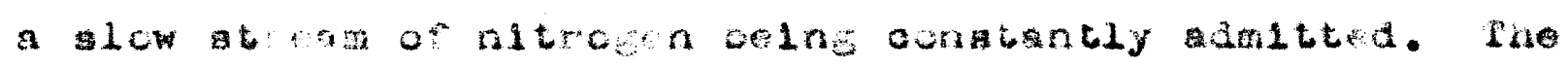

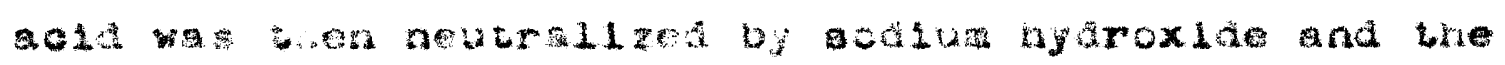

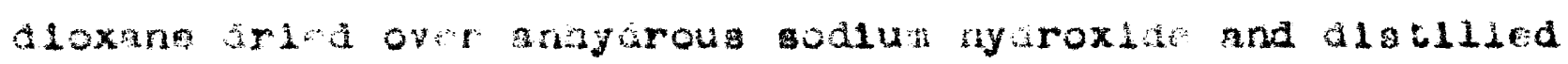

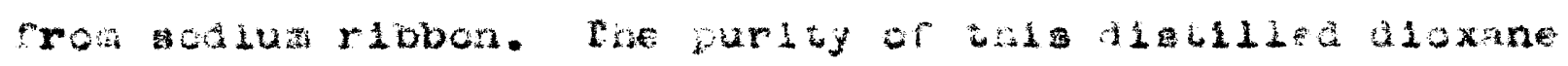

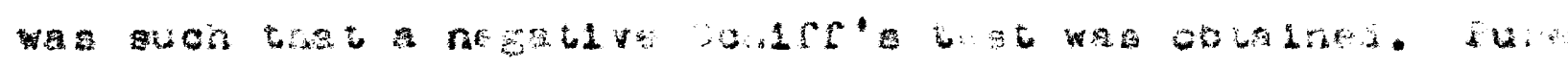

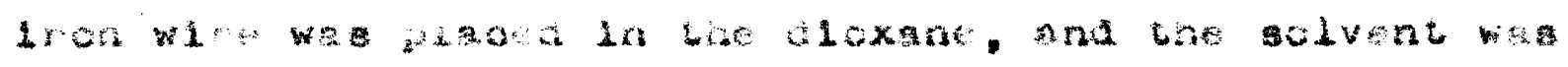

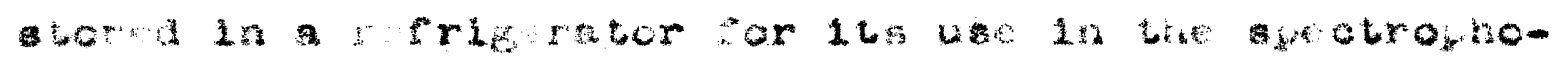
tome $\mathbf{r}$

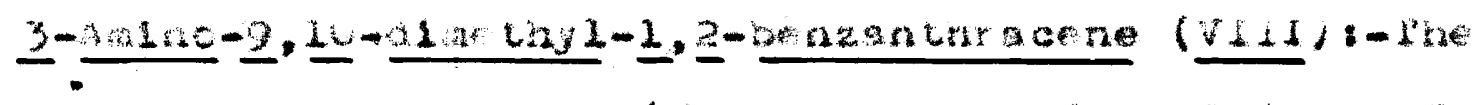

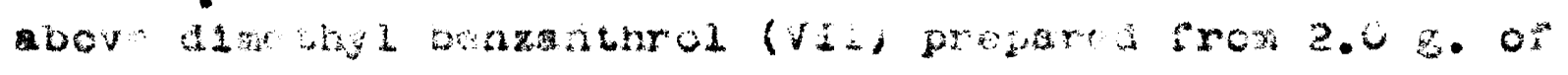

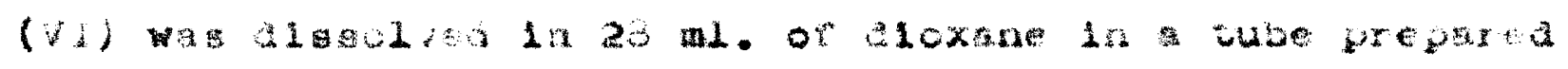

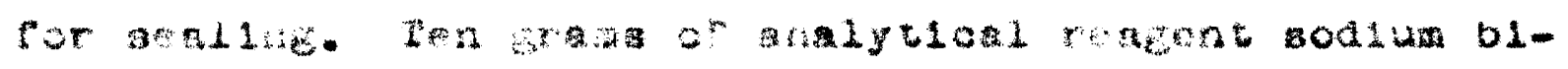




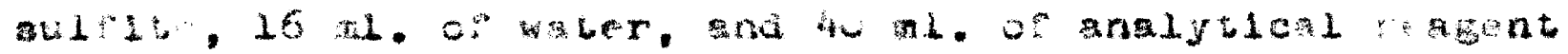

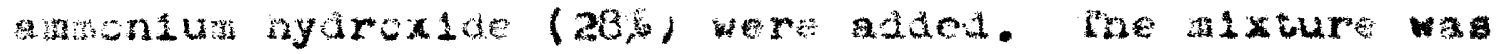

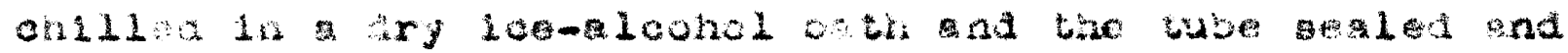

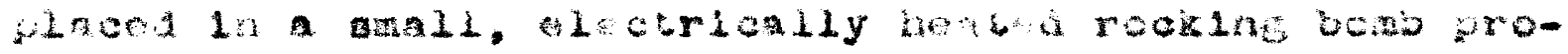

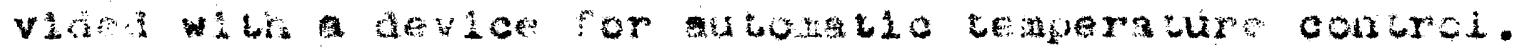

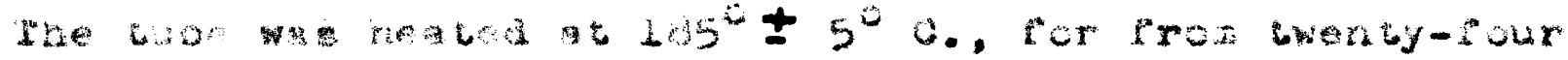

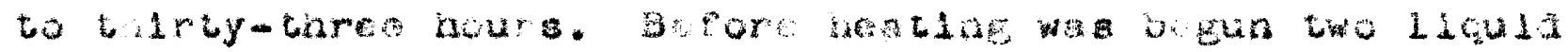

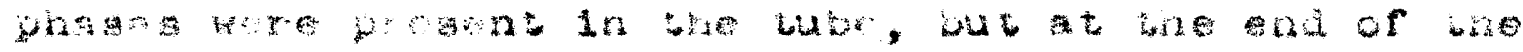

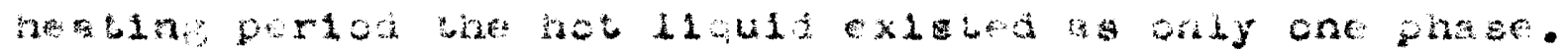

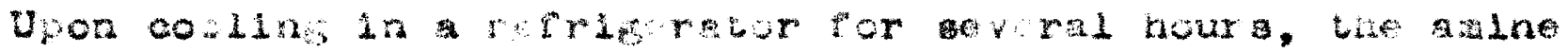

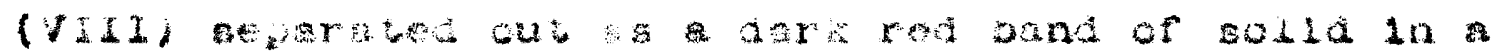

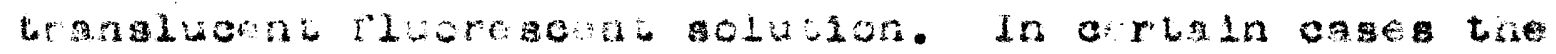

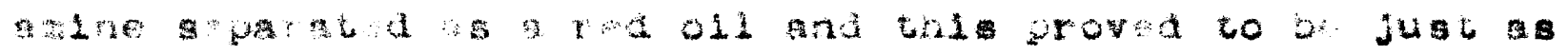

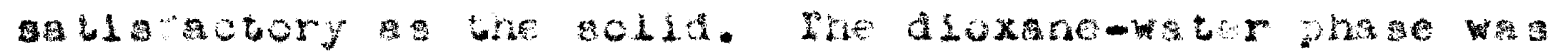

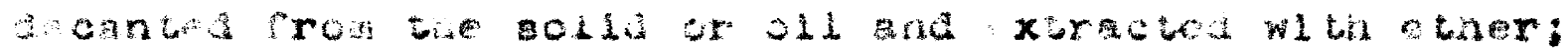

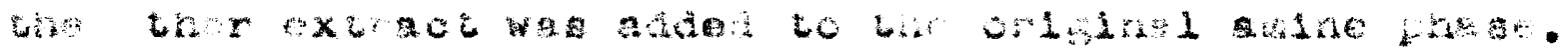

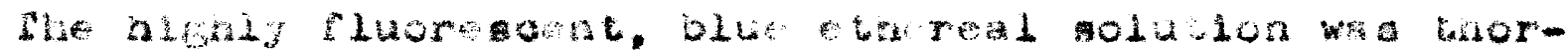

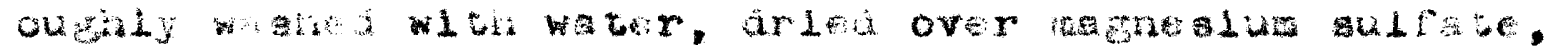

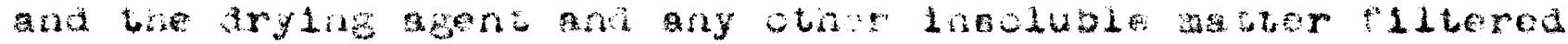

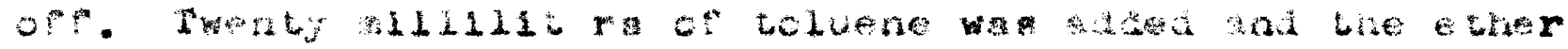
was a

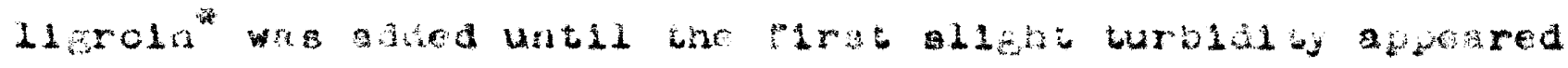

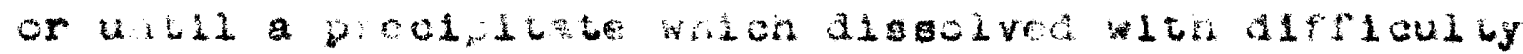

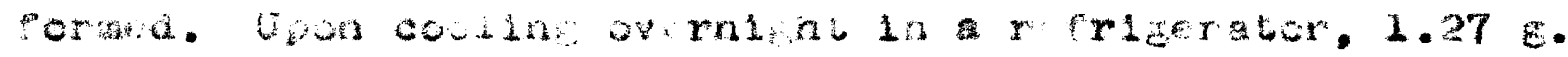

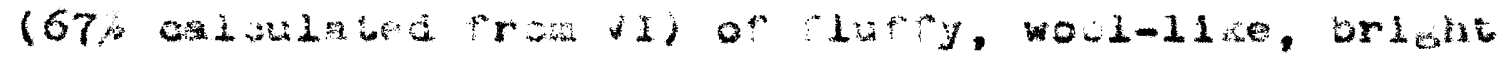

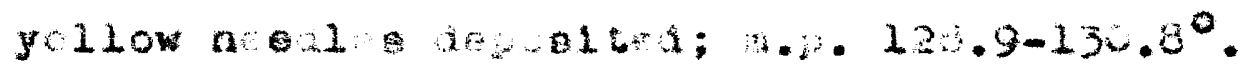

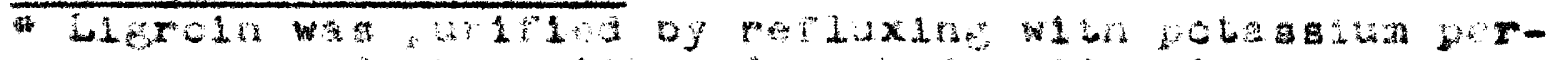

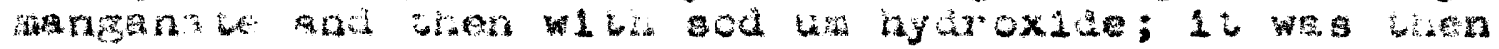
as 1111.0 


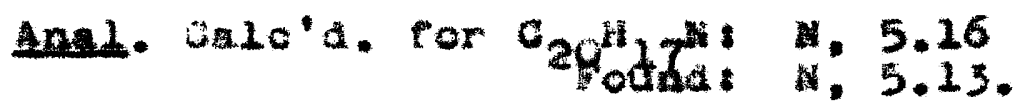

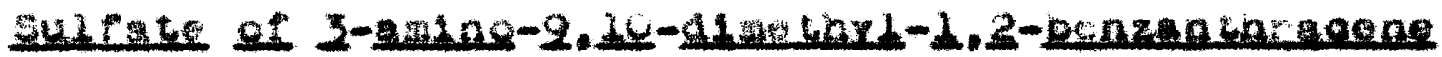
(VIXI D)t-It was found that the aulf te of the alne was a convanient darlotive. It wa preparca by dropwibe addition or colution of 5 arope of conoentabed sulfurie acia in $10 \mathrm{ml}$. of ankydrou aloohol to a solution of 50 afe of the

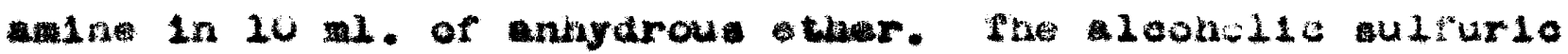
add wa added until no more anine procipltated. The green-

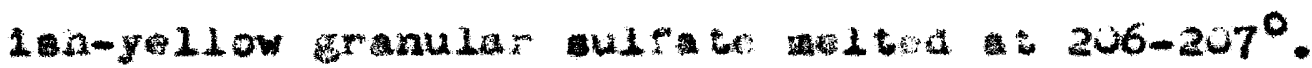

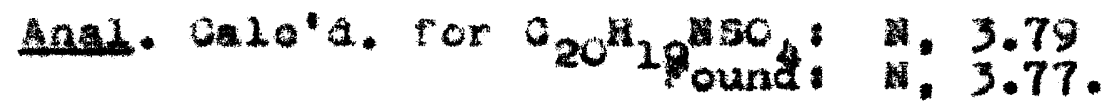

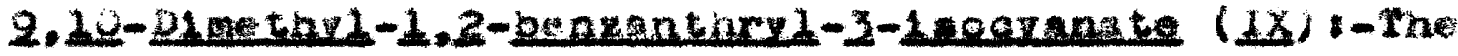
lacoyanate could be readily preparat whout 16olation of the pure, orytaline mine. Two grata (0.007 motes) of

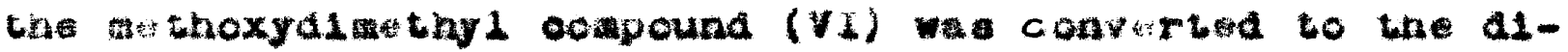
we thylbonanthrol (VII) and unlo wa oployed in the Bucharer reabion a descrlbed above. Pbe arled ther solution of the arino-a1betayl conpound (VIII) obtalned a previous-

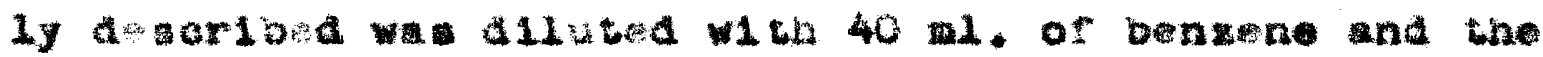

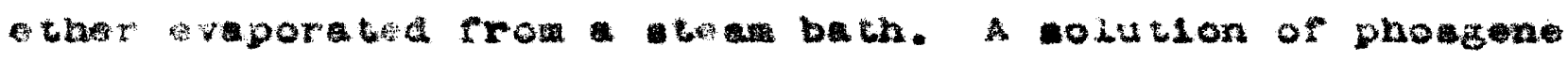

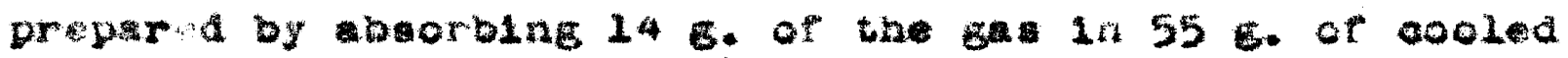
tolueno wa added to the warmed benzene solution of the abine. 15

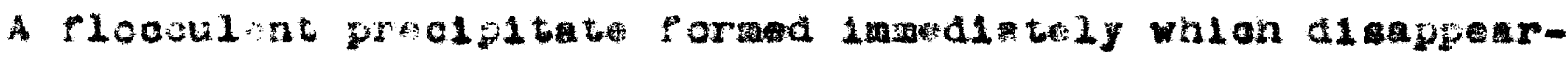

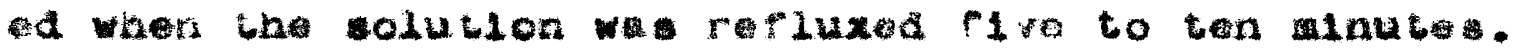
After regoval of about two-thira of the bolvent by dia-

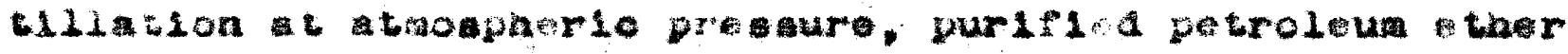

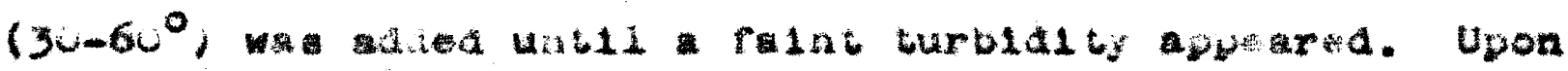

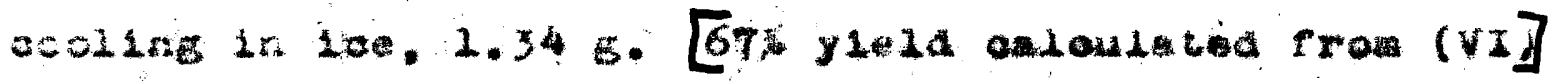




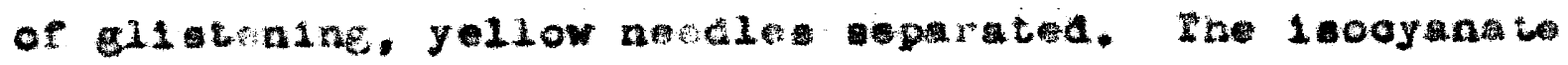

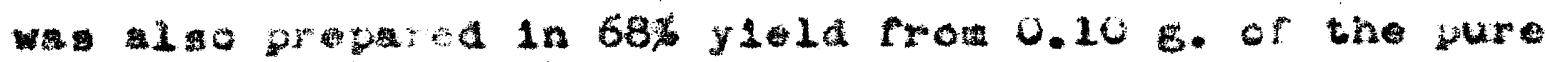

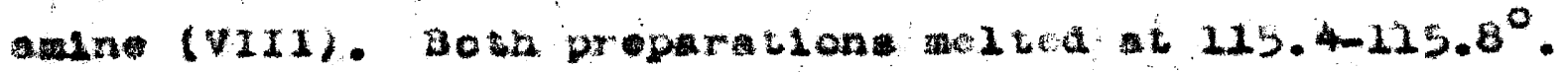

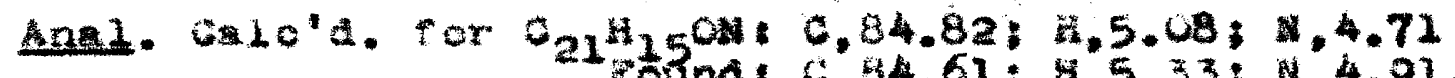
round: $0.34 .61 ; 4,5.33 ; 1,4.91$.

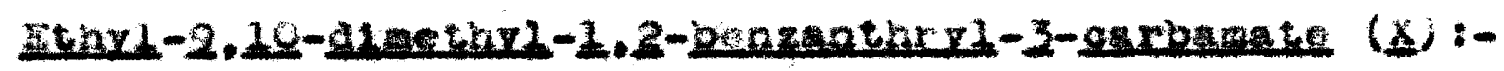
The anbate proved to be a sultale derlvative of the

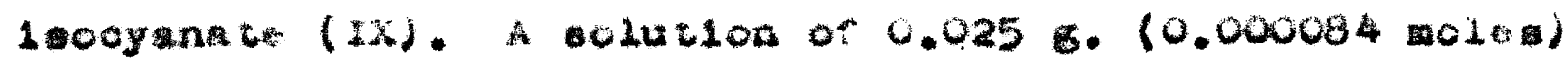
of the loocyanste in 25 . of brolube lcohol wa rerluxed

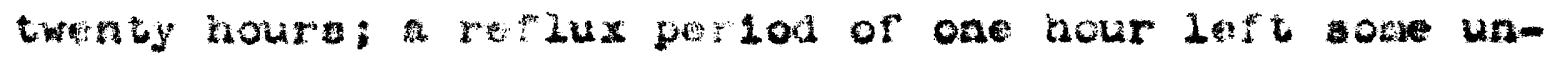

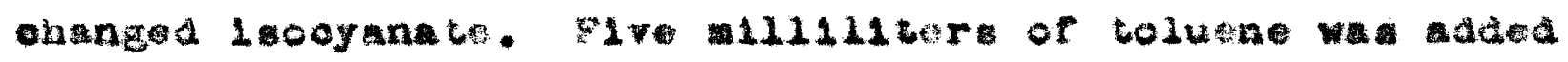
and the solution $x$ tracted with watr and aried over astne elum culfat. Petroleum ether $\left(30-60^{\circ}\right)$ wa adad and upon oodlne $0.018 \mathrm{~g}$. (63\%) of pale yellow needle oryelall1zed. the line point wa $113.3-114.1^{\circ}$; adsaluture win (IX) gave and lowering.

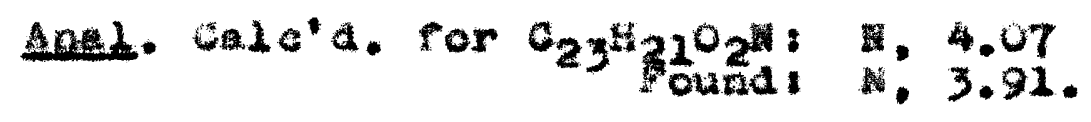

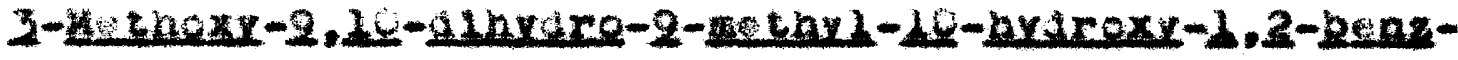

anthrageng ( 1 A) in solution of $29.4 \mathrm{~g}$. (0.102 molas) of orude anturone (IV), progared aevorlboa above, in 250 al. of anhydrous lecprogl lcohol wa tirred eflolently during the siltion of three nolar quivalute $(62.4$ s.) of aluminu lapropoxide. Arter the mixture had boen repluxed for sevon houra, rolatlle terlal wa aloly removed

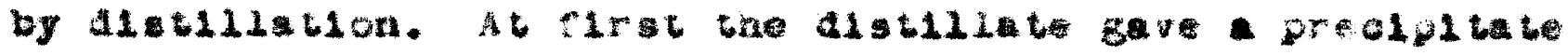
with 2,4-dinitrophenylnydrazine, but this tost wa negative after most of the volatile wherlal wa removed. In order

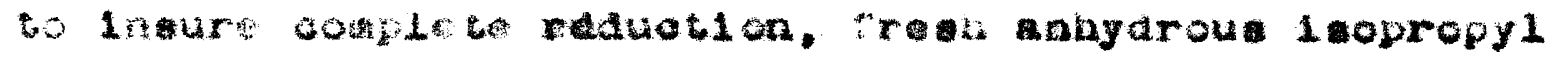




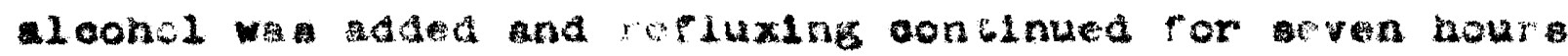

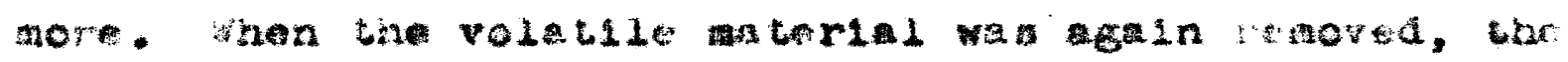

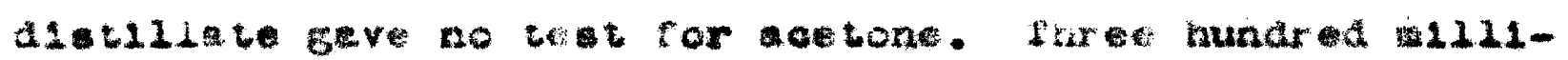
11twre of water-hykrochlcwie wold $(3: 1)$ was adad to the waction alxtur and the anthrol wa then extratod lato

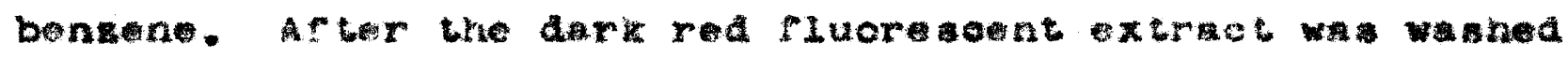

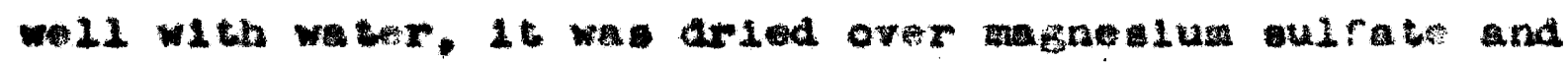

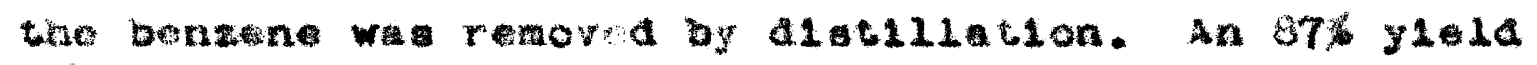

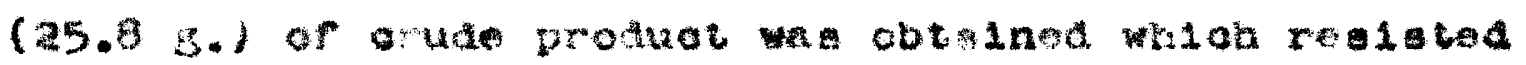

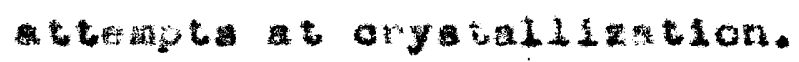

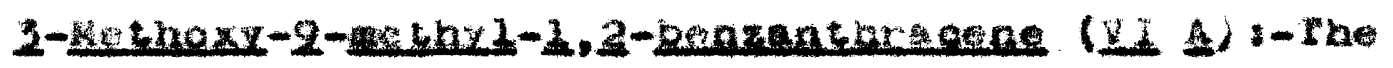

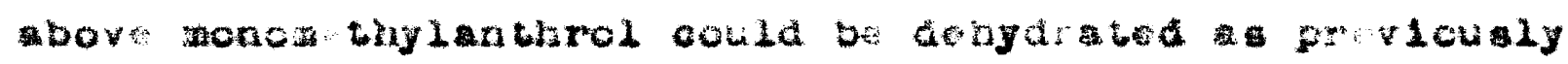

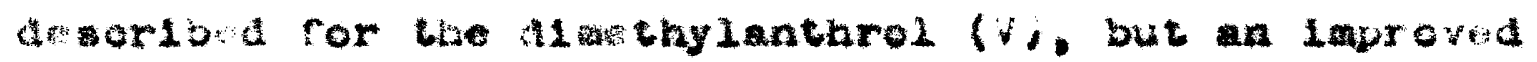

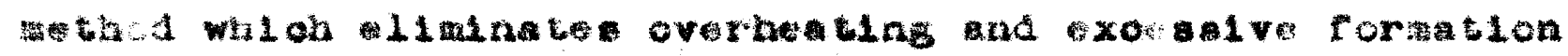
of tar wa dovisod. Arter the notone and noat of tho

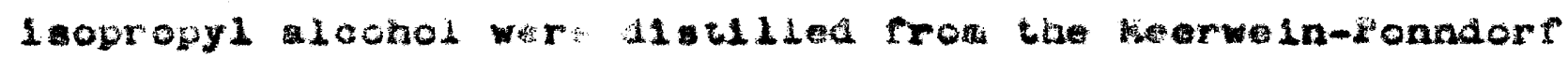

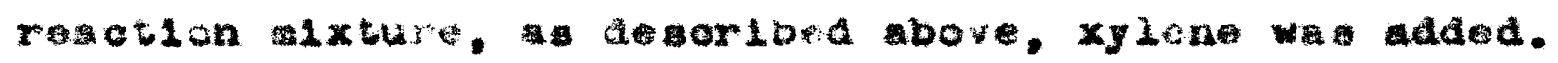
Upon further dat112aton the anthrol dehydratod, and the water wa removad ezeotroplanily whout danger of deoumpottion of tho thoxycthyl benzanthracene (VIA). Inpurlties were ramoved from benzene colution or the erude proulut s dearlbat for the analozou ooupound (vi). Upon comcentration ana cooling of bue benzenteolution whon

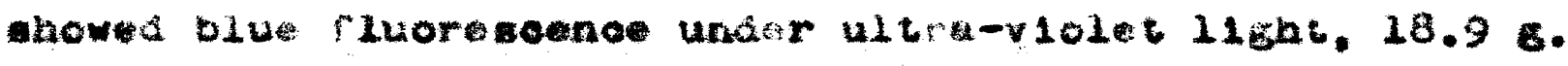

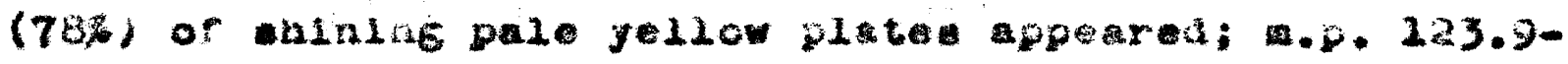
$124.3^{\circ}$. SInce 32.0 6. (0.104 mola) of the subetituted

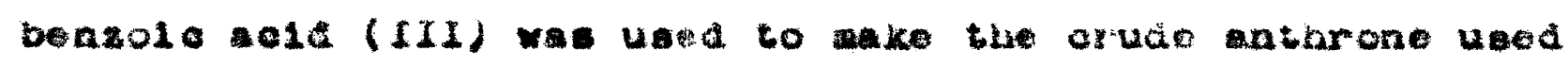

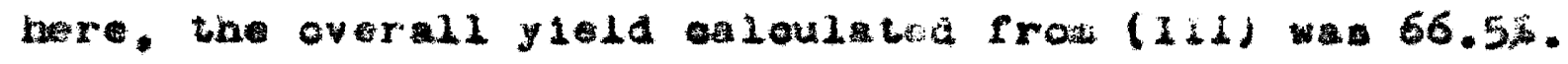




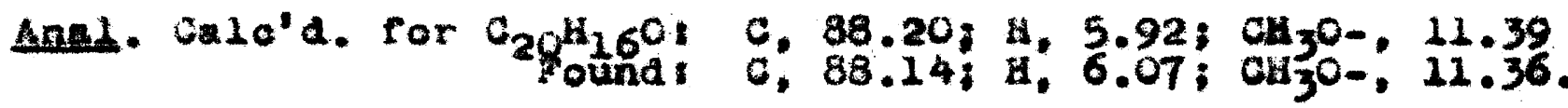

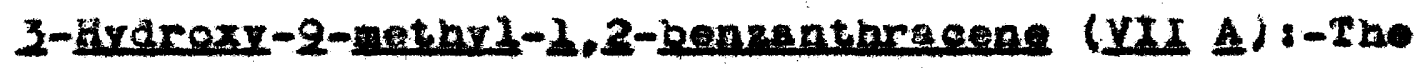
converalon of (VI A) to (VII A) wa earried out exmotly a desoribed for the corresponding dimethyl compounde. (VI) and (VII). In order to racklitate handing the product as to arola deocmposition, only 2.0 E. $(0.0073$ moles) of the methoxy compound was treated at a time. 3-Amlno-2-methe2-1.2-bencanthraene (ULdI A) I-The methylbenzantirol (VII A) prepsred from $2.0 \mathrm{~g}$. of the methoxy compound s jut desorlbed, was dissolved in dioxane and trented as previouly denoribed for the analogou dmethyl compound (VIII). After oompletion of the roction, the gealed tube wa placed in the refrigerator overnight. phe free sine crystallzed out beautiful yellow-whlte rosettes and long, nicely-maped neades. Aldo of solle al so formed which wa found ugon deroscople examination to be componed or we11-formed needien. Thl and was waned well with water sha then dried in a voutu dealocator at room tomperature. Sinoe the amine is seneltive, it must be aried oarefuliy at low temper tures until preotleally all of the water to remorod. The product melted at 112.1$115.9^{\circ}$ and welghed $1.76 \mathrm{~g}$. ins torresponde to $93 \%$ overal yiela from (VI A). Although thl materlal gave good ylelda when converted to the leogranate, absolutely pure alat wa preparid by recryataliliation. The alne was diesolvad in ether na allght anount of terist belleved to be (VIII C) was reaored by filtration. After the 
adation of tolueno not of the wher ras evaporated. Upon cooling the aolution of antine in ary loe-aloohol bath, nedue were obtalned whioh had to pe flitered off rapialy Ine they rediesolved resdily. By reeooling the flltrate and reflitering total of $1.21 \mathrm{~B}$. [64.5\% caloulated frow [VI A], of pure anine whloh welted at $116.6-117.4^{\circ}$ vae obtolned. It should be emphasiced that the unrecryetallized amine, obtalned as desoribed above in $93 x$ gleld, oould be ued to better surantage for converalon to the methylbenzanthry $1-1$ cooyanate (IX A) a acsorlbed below.

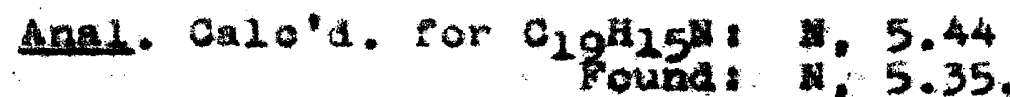

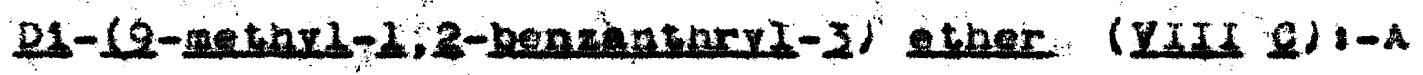

material belloved to be this compound remalned a bioty

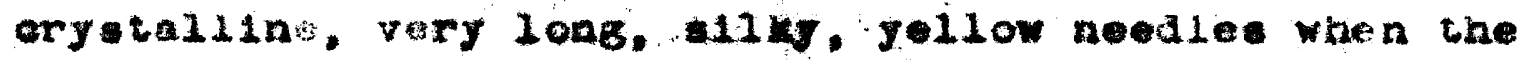

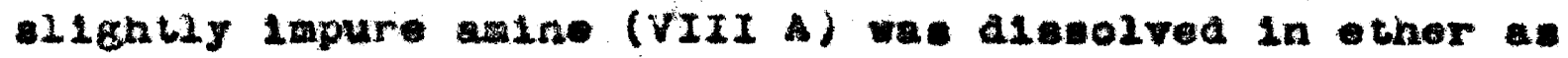
juat desorlbed. In varloue mane the amount of this materal obtained raried erom none up to $0.13 \%$ of the welght of the de Ired alno ocmpound (VIII A). The elementary composition and the molecular welght by the pat mathod agread alobely win that caloulated for (VIII $C)$. The compound decompoed at $270-271^{\circ}$.

402. ft. Oalo'd.: 493.6; Found: 496

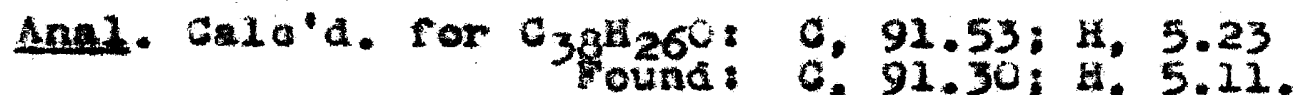

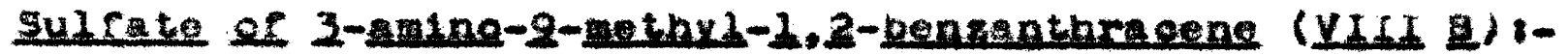
This eat wa propared in a manna exaty analogous to that previoualy deseribed for (VIII D). Upon addition of eulfuric acla in aloonol to the ther colution of (VIII A). a 
Eraylin whit, granuiar aolid preclpitated. This compound decompoesd very harply without welting at $218.7-219.0^{\circ}$.

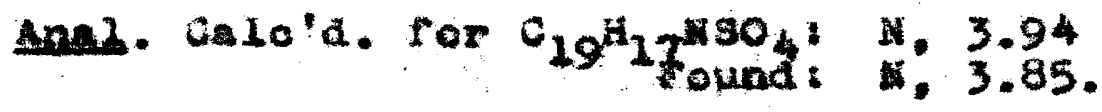

\section{2-1ethol-1.2-berranthrud-3-1nocrangte (IX A):-The} alghtly impure andine (VIII A) melting at $112.1-115.9^{\circ}$ wa the startine material for the preparation of thl 1 sooyanste. Phreo-tenthe of gram $(0.00116$ moles) of this amine wa dissolvod in ether, any inooluble matarial we f1ltered off, and $10 \mathrm{ml}$. of benxene added. A aclution of $2.65 \mathrm{E}$. of phoagene in $11 \mathrm{ml}$. of toluene wa added to the warm oolution of the amine. The precipltato which rirat appeared, rediasolved after the mixture was refluxed rive to ten minuto. Arter removal of wost of the solvent by Alstiliation at atmoepber10 preseure, petroloum ther $\left(30-60^{\circ}\right)$ wa added unt11 a sight turbldity apperard. Upon cosling ovinight in a refrigerator, 20rib, elender, well-formed needies appeared which beame bulky and compact upon further growth. The produst we1ghod $0.238 \mathrm{~g} .(73 \%$ 51eid) and melted at $63.0-64.2^{\circ}$. Frequently it wa neceasary to ocneentrate tho solution rurther and to uee esed eryatele In order to obtaln oryatal11ae produet.

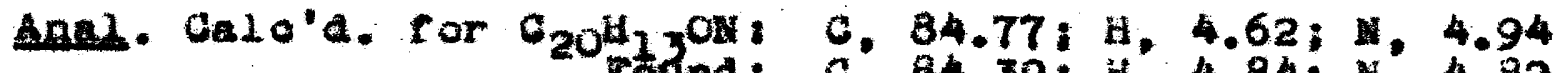
Forind: $0,84.39 ; 1,4.84 ; 1,4.82$.

Ethol-2-pethol-2,3-benzenthrol-3-earbenate (X A):-A oplution of 0.04 6. (0.00024 moles) of the laogyanate (IX A) In $10 \mathrm{ml}$. of anindrous alcohol wa refluxed for tan houra. 51x mill111ters or toluene was aded and the oarbamate oryatall1zed as decribud above for $(x)$. A $65 \%$ yleld 
$(0.030$ s) of pale yellow noed16 whon welted at $174.2-$ $174.9^{\circ}$ was obtsined.

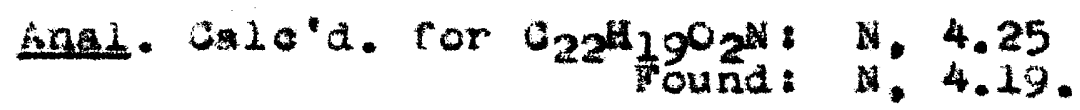

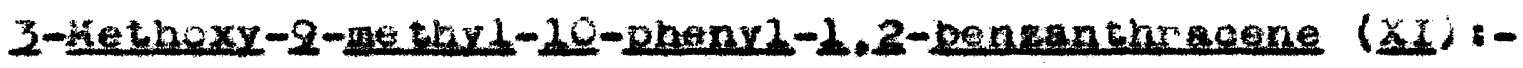
orudz anthrone (IV) preparea from $25 \mathrm{~B} .(0.082$ moles) of the substituta bonzolo acla, described above, wa diseolved in one liter of benzene. This solution was added to a colution of phenylagenesium bromat prepar from $3.0 \mathrm{E}$. of maneslum and $20.0 \mathrm{~g}$. of bromobenzene in one 11tor of anhydrous ther. After the ouspeneion of the mudyellow complex wa rafiuxed for twolve hours, the mature wa decomposd with oulfurle acld and loe. The lajers were separatod, the quocus inger wa extractod with benzene- ther $(1: 1)$, ana the extracts were saded to the orlelnal nonsqueous laytr. The comblned colutions ware wabed with dilute sodium carbonats, and then with water and arled over agnesitu sulfete. After removal of the solvent by ditiliation, the intermatate tertiary alcohol was dehyderta by hoatine for few inutes on hot plate. Considerable furirlogtion wa acconglianed by convrting the desired product to the plorate and aparating $1 \mathrm{t}$ frow lapuritles by chromatographlo adsorption a previcualy describra for tine analogoun almethyl compound (VI). Attempte to obtain puro aryatal prom tho yellow colution

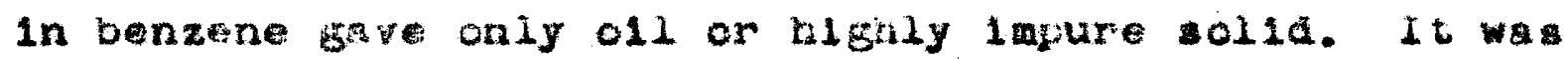
found that subliation rollowed by moleoular distllation gave 23.0 8. [31\% cloulated rrom (III) or an orsinge, 


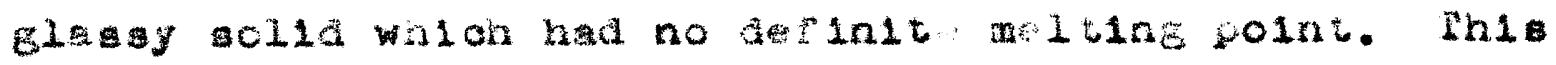
conquaci in benzene oclution ahowed intrnas blue fluores-

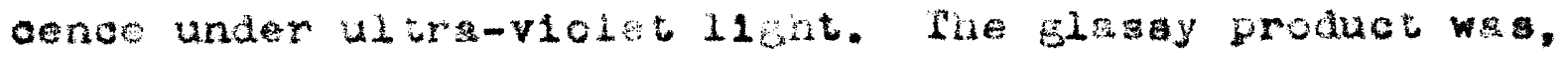
acouding to elementary and athoxyl analyala, of nibl

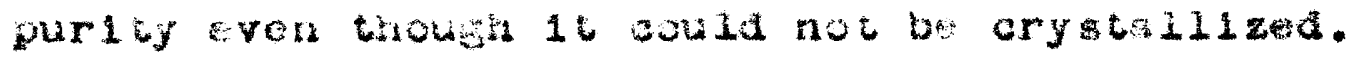

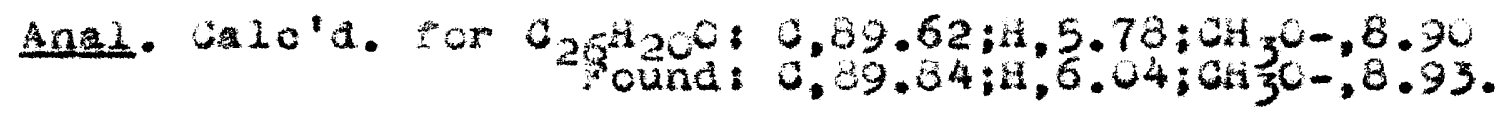
2-

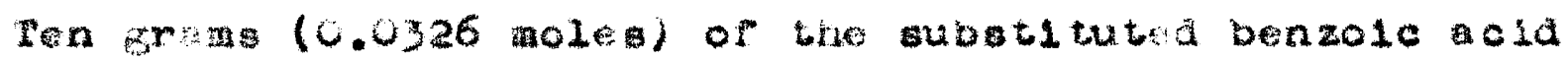
wa converted to the orude anthrone (LV) In the var manner. Ihie antirone diaolved in 200 ml. of benzene was adaed to an axces of etrymanesium bromide prepared in 500 . of nhydrous ther rrow 1.2 g. of magne lua and 5.3 6. of thy 1 brombe. A prelpltate formed and green color apond whon ong ned to yellow when the sulure wa refluxed fleten hours. The comlex wa decoposed and the trt15y alooho. Interafiate wa laoleted and dehyarated to (XII) desoribed for (XI) just above. Ine plorate wa formed and the ark red, viacus oll was chromatorrphea. Good separtion wa obtained on the adsorpion colum. A banene achution of the destred produet showed

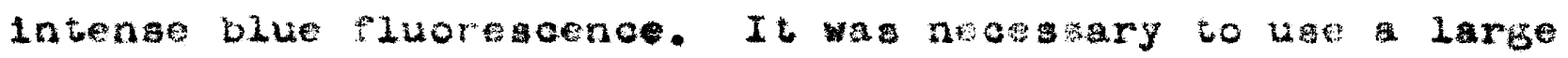
voluge of petroleun ther $\left(30-60^{\circ}\right.$, for orymtallization.

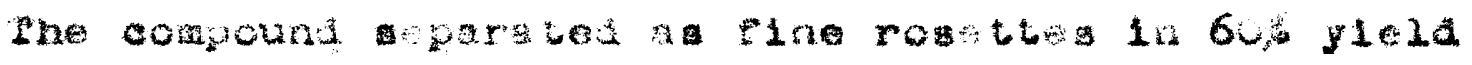

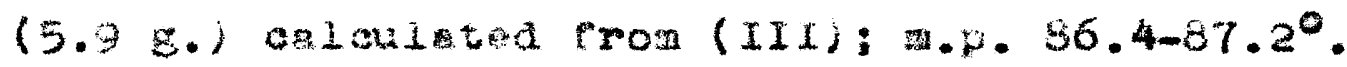

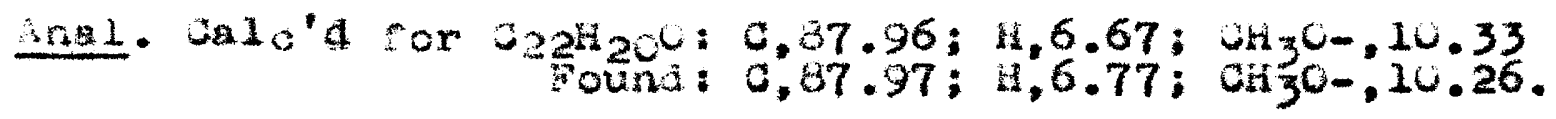

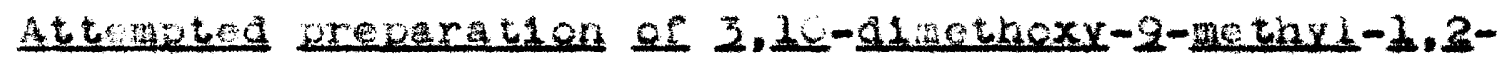
benzantiargane (XII):-Crude anturofe (IV; prewared iron 
10 g. (0.0326 noles) of the subatituted benzole sold in the ubual anner wa rofuxed for alx hour in $150 \mathrm{mal}$. of analytion reazent pyriane. This baso tratment tautomerlizes the anchrove to the anthrol. 19 The pyridue solution of the anthrol was adied to large exces: of diazo-

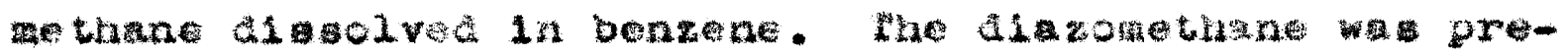
pared fros 0.1 aola or N-nLtrosomsthyluxea by well known sethod. ${ }^{1}$ The tomperature wa ket at $5-10^{\circ}$ durlag the

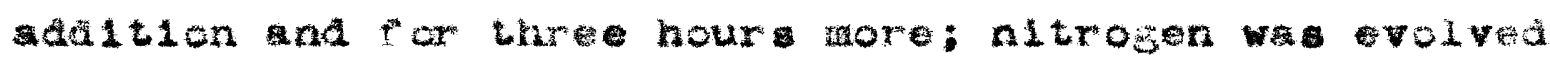
copiouly during tin perlod. After the noiution wa Allowed to wari up and tand at roon temperature for twelve hours, an atterpt was ade to extract the pyridine into wher. Since this produced an etmuleion the solvents were ditllied of the brom-black resldue wo treated with benzera, lagcluble atter wa filtred off, and the filtrate wa tretod wh ploric acid. When this benzene golution of the plorato was gad throuth a colum of aludas, the reatling bolution showed a bright green

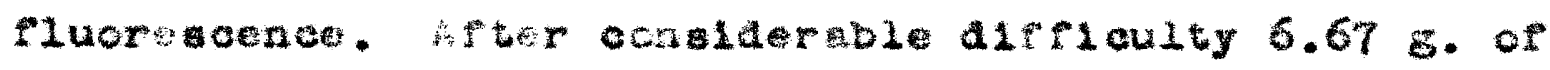
lere, yellow rectangular plato orystallized frow hibhly concentrated benzene sclution; w.p. 148.2-149.6.

$$
\begin{aligned}
& \text { Ana1. Cald'd. for } \mathrm{C}_{21} \mathrm{H}_{18} \mathrm{O}_{2}: 0,93.41 ; \mathrm{K}, 6.00 \\
& \text { balo'a. ror d2011603: c, 78.80: H, } 5.30
\end{aligned}
$$

The above analyal ahow that the expectad disothexy compound (XIII) wa not ootaned. It is indiated that lastead o: abstituting a hydrocen atow of the anthrol by

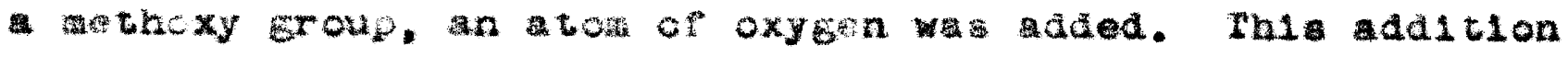
of oxygen hisht have been expectad alnoe Dufralase and 


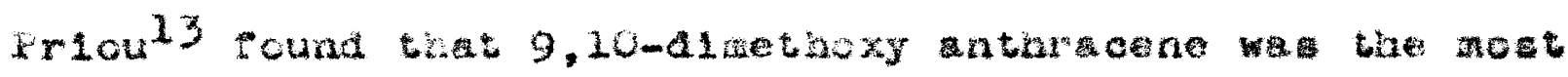

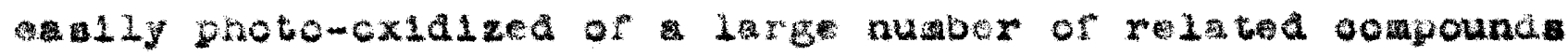
which he tualed. wo proof of struature or other oharacter-

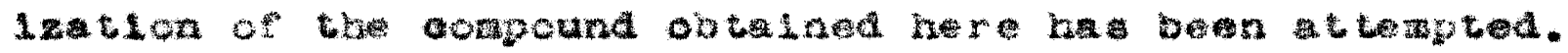


SELCC

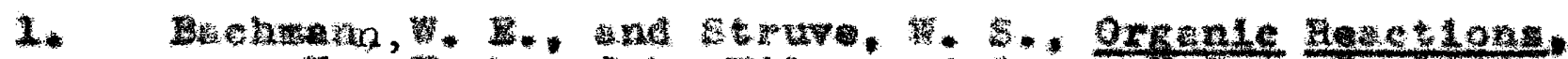

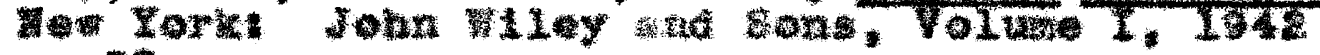
1.

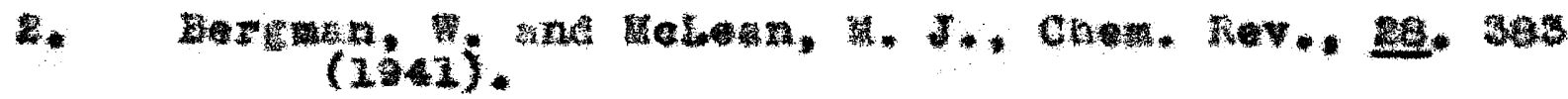

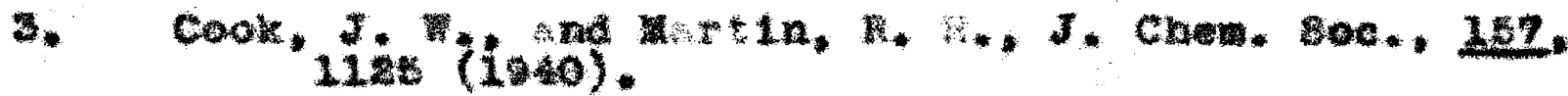

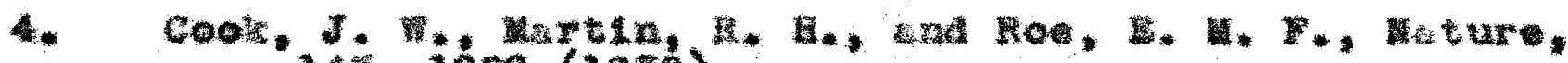
145. $1020(1030)$.

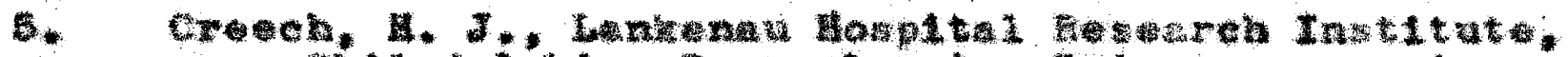

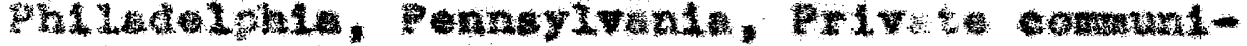
- atan to the athor.

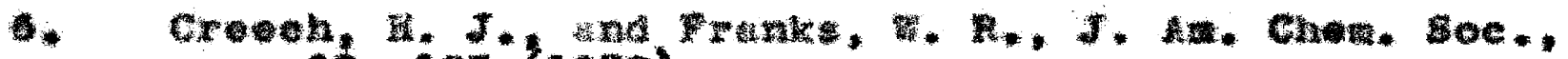
b0. $127(1958)$.

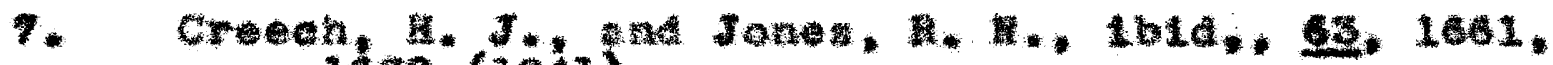
$1690(184 x)$.

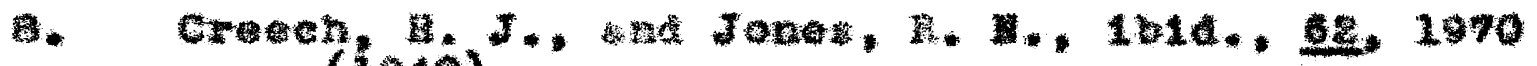
(1340).

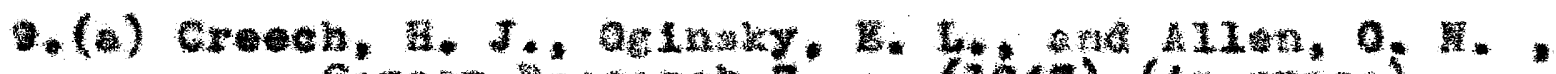

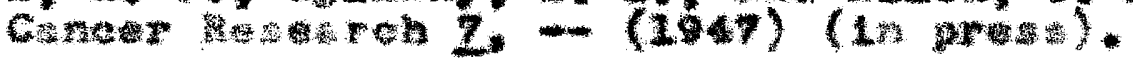

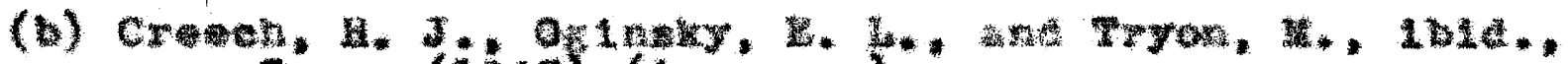
1. - (1647) (in protis).

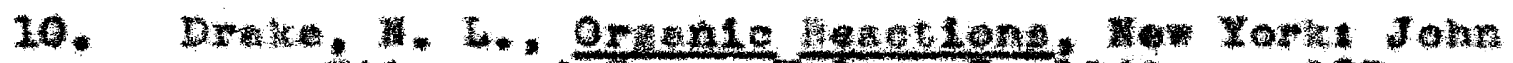

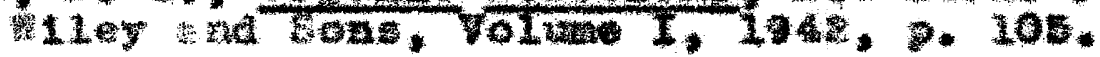

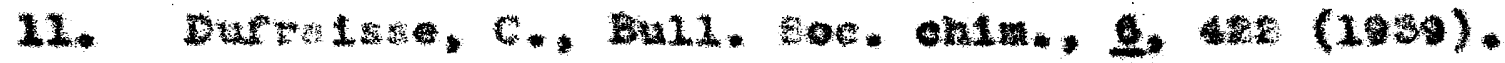

12. Dufrols

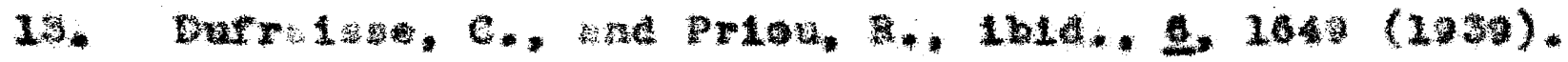

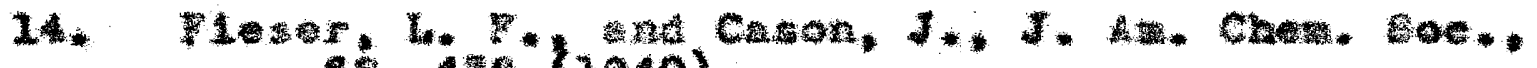
6. $(1940)$.

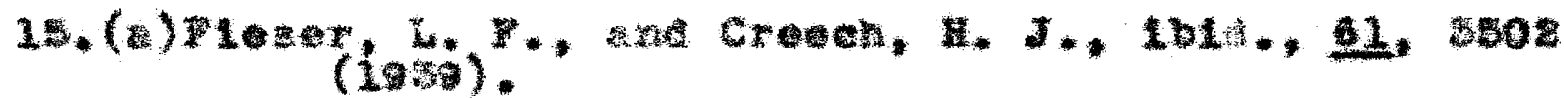

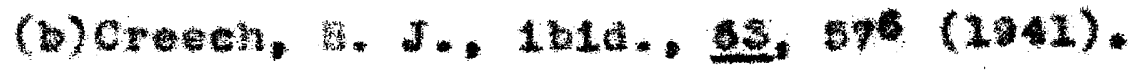

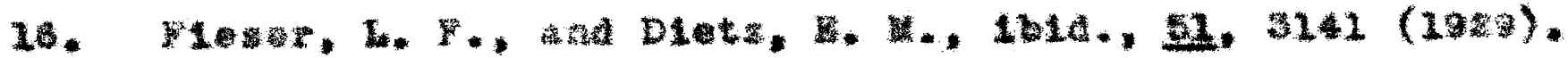

